\title{
Phytochemical and Ethnopharmacological Perspectives of Ehretia laevis
}

\author{
Pooja Sharma ${ }^{1,2}$, Richa Shri ${ }^{1}$, Fidele Ntie-Kang ${ }^{3,4, *}$ and Suresh Kumar ${ }^{1, *}$ \\ 1 Department of Pharmaceutical Sciences and Drug Research, Punjabi University, Patiala 147002, India; \\ poojasharmagndu@gmail.com or pooja.sharma2007@yahoo.co.in (P.S.); rshri587@hotmail.com (R.S.) \\ 2 Sri Sai College of Pharmacy, Manawala, Amritsar 143001, India \\ 3 Department of Chemistry, Faculty of Science, University of Buea, Buea P.O. Box 63, Cameroon \\ 4 Institute for Pharmacy, Martin-Luther-Universität Halle-Wittenberg, Kurt-Mothes-Str. 3, \\ 06120 Halle, Germany \\ * Correspondence: fidele.ntie-kang@ubuea.cm (F.N.-K.); thakur_pu@yahoo.com (S.K.)
}

\section{check for} updates

Citation: Sharma, P.; Shri, R.; Ntie-Kang, F.; Kumar, S.

Phytochemical and

Ethnopharmacological Perspectives of Ehretia laevis. Molecules 2021, 26, 3489. https://doi.org/10.3390/ molecules26123489

Academic Editors: Diego MuñozTorrero, Michael Gütschow, Maria João Matos, Luciano Saso, Maria Emília de Sousa and Simona Rapposelli

Received: 1 May 2021

Accepted: 2 June 2021

Published: 8 June 2021

Publisher's Note: MDPI stays neutral with regard to jurisdictional claims in published maps and institutional affiliations.

Copyright: (c) 2021 by the authors. Licensee MDPI, Basel, Switzerland. This article is an open access article distributed under the terms and conditions of the Creative Commons Attribution (CC BY) license (https:// creativecommons.org/licenses/by/ $4.0 /)$.

\begin{abstract}
Ehretia laevis Roxb. (Boraginaceae) has been extensively used as a traditional remedy for the treatment of a diverse range of ailments related to the respiratory system, the gastrointestinal tract, the reproductive system, and against several infections. This review critically assesses and documents, for the first time, the fragmented information on E. laevis, including its botanical description, folklore uses, bioactive phyto metabolites and pharmacological activities. The goal is to explore this plant therapeutically. Ethnomedicinal surveys reveal that E. laevis has been used by tribal communities in Asian countries for the treatment of various disorders. Quantitative and qualitative phytochemical investigations of E. laevis showed the presence of important phytoconstituents such as pentacyclic triterpenoids, phenolic acids, flavonoids, fatty acids, steroids, alkaloids, aliphatic alcohols, hydrocarbons, amino acids, carbohydrates, vitamins and minerals. Fresh plant parts, crude extracts, fractions and isolated compounds have been reported to exhibit broad spectrum of therapeutic activities viz., antioxidant, antiarthritic, antidiabetic, anti-inflammatory, antiulcer, antidiarrheal, antidysenteric, wound healing and anti-infective activities. E. laevis is shown to be an excellent potential source of drugs for the mitigation of jaundice, asthma, dysentery, ulcers, diarrhea, ringworm, eczema, diabetes, fissure, syphilis, cuts and wounds, inflammation, liver problems, venereal and infectious disorders. Although few investigations authenticated its traditional uses but employed uncharacterized crude extracts of the plant, the major concerns raised are reproducibility of therapeutic efficacy and safety of plant material. The outcomes of limited pharmacological screening and reported bioactive compounds of E. laevis suggest that there is an urgent need for in-depth pharmacological investigations of the plant.
\end{abstract}

Keywords: Ehretia laevis; pharmacological activities; phytochemistry; traditional use

\section{Introduction}

Ehretia laevis is a rapidly growing medium sized tree of the Boraginaceae. The genus Ehretia contains more than 150 species [1]. The plant is primarily distributed throughout tropical and subtropical regions of Asia, Africa and Australia [2]. E. laevis is the most popular member of its genus and is commonly known by more than 120 names in diverse languages (see Supplementary Materials Table S1). In India the plant is mainly found in the Northern parts of the country (e.g., in Bengal, Maharashtra and Rajasthan) $[3,4]$. The plant has also been documented in the traditional system of medicine (e.g., Ayurveda and Siddha). This is due to its extensive uses to treat respiratory system diseases (e.g., asthma and cough), gastrointestinal tract infections (e.g., jaundice, diarrhea, ulcers, dysentery, liver diseases), endocrine system diseases (e.g., diabetes mellitus), microbial infections (e.g., diphtheria, scabies, ringworm, gonorrhea, syphilis and venereal diseases) [5]. Some pharmacological screening studies have been performed to authenticate its traditional claims. 
Moreover, several bioactive metabolites such as pentacyclic triterpenoids, phenolics, flavonoids, tannins, fatty acids, vitamins, minerals, amino acids and carbohydrates have been isolated from it's crude extracts [6-9]. Several research groups have shown the presence of alkaloids, glycosides, flavonoids, phenolic acids, tannins, saponins, proteins and carbohydrates in the plant [10]. The pharmacological activities and outcomes of these investigations have not been able to sufficiently authenticate the possible mechanisms of action of these molecules. Therefore, the plant should be subjected to mechanistic studies at the molecular levels.

Additionally, only a few toxicity studies have been published yet, including acute oral toxicity studies on the crude extracts of E. laevis, confirming that the plant is safe through oral route at the dose of $2000 \mathrm{mg} / \mathrm{kg}$ [8]. Until now, not even a single study has been performed in detail for clinical trials. So, detailed toxicity, preclinical and clinical trials on the plant should be carried out in order to ensure its clinical efficacy and safety in humans.

However, no review is currently available which covers all aspects of E. laevis. The present review article covers botanical distribution, conventional uses, phytomolecules, toxicology and scientifically verified pharmacological activities of the plant and its metabolites, this justifying this review.

\section{Materials and Methods}

All pertinent information about the botanical description, conventional uses, phytomolecules and pharmacological activities of E. laevis were collected from available literature. The electronic databases employed for the assortment of relevant information include Scopus (accessed on 1 May 2021), NISCAIR (accessed on 1 May 2021), Scifinder (accessed on 1 May 2021), PubMed (accessed on 1 May 2021), Springer Link (accessed on 1 May 2021), Science Direct (accessed on 1 May 2021), Google Scholar (accessed on 1 May 2021), Web of Science (accessed on 1 May 2021) and exhaustive library search. The chemical structures of compounds were drawn using ChemDraw Ultra 8.0 software (PerkinElmer, Waltham, MA, USA). Pubchem (accessed on 1 May 2021) and ChemSpider (accessed on 1 May 2021) database has been used to check the IUPAC names of the isolated phytoconstituents.

\subsection{Botanical Description}

Ehretia laevis is a medium sized tree reaching up to the height of $12 \mathrm{~m}$ (Figure 1). Its dropping branches bear dark green colored leaves with varied size 2-7.8 $\mathrm{cm}$ in length and $1.2 \mathrm{~cm}$ to $3.8 \mathrm{~cm}$ in width. The shape of leaves is obtuse; with 5 to 7 lateral veins on each side of the mid rib with a slender $2-3 \mathrm{~cm}$ long petiole. The bark of the plant is irregular and light grey. The flowers are white, with round orange fruits when ripe or mature [11,12].

\subsection{Geographical Distribution}

E. laevis is mainly cultivated in India, China, Pakistan, Sri Lanka, Africa, Bhutan, Nepal, Burma, Vietnam and Australia. The plant is mainly located in hilly forests and on hilly slopes [2,13]. 


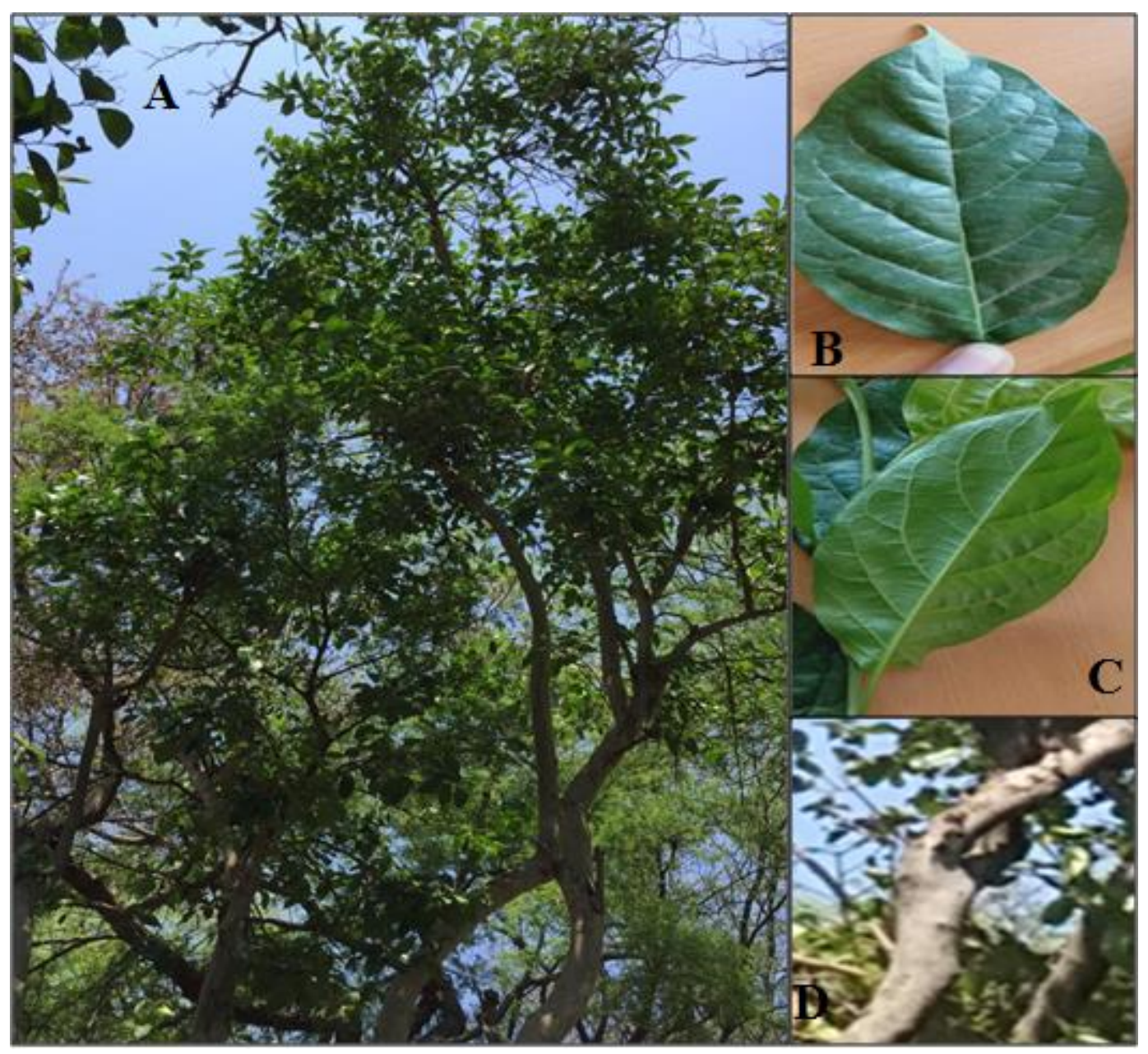

Figure 1. E. laevis tree (A); dark green leaf (B); leaf venation (C); stem-bark (D).

\section{Local and Contemporary Uses of E. laevis}

Several parts of E. laevis have been widely used for the traditional treatment of several disorders, including its leaves, barks, stems, seeds and fruits in different forms alone and sometimes also in combination with other herbs [5,8]. In Ayurveda E. laevis had been documented for its use in the treatment of asthma, diphtheria, cuts and wounds, astringent, fractures, demulcent, diarrhea, dysentery, toothache, cough, syphilis, gonorrhea cachexia, and venereal diseases $[5,14]$.

It was found that various tribal communities used paste prepared from the leaves of E. laevis for the relief of acute and chronic inflammatory disorders [15]. Similarly, the folklore practitioners from Dhule district of Maharashtra recommended the use of the stems of E. laevis to treat ulcers and gum problems [16]. The leaf paste is also used for the management of fissures in the Wardha district of Maharashtra [17]. The Garasians tribes of Rajasthan use a decoction prepared from the plant bark for the relief of asthma, cough, cold and delivery pain [18]. In addition to this, an ethnobotanical survey conducted among elderly persons and traditional healers of tribal communities in the Jalpaiguri district of West Bengal revealed that the paste prepared from the bark of this plant relieves pains, especially in the lower limbs [19].

Another survey conducted on Gujjar tribes of Uttarakhand reported that E. laevis had been greatly used for the treatment of liver diseases, e.g., jaundice. A paste of soaked seeds of E. laevis was prepared, mixed with powder of Amomum subulatum and given thrice a day with milk by Nomadic people for the treatment of liver diseases [20]. Furthermore, an ethnobotanical survey has been conducted in the Tharu community of district Udham 
Singh Nagar, Uttarakhand, India. It was found that local villagers and health practitioners used the paste prepared from the seeds of E. laevis for the healing of skin diseases [21]. Leaves, stems, barks and fruits of E. laevis are also used in the manufacturing of dyes, cosmetics and wines [2,22]. All the local and contemporary uses of E. laevis mentioned in Ayurveda, Siddha and ethnobotanical surveys reports have been summarized in Table 1.

Table 1. Local and contemporary uses of E. laevis.

\begin{tabular}{|c|c|c|c|c|c|}
\hline S. No. & Ailment/Use & Part of Plant & Locality/System of Medicine & Preparation Used & References \\
\hline 1 & Abdominal pain & All parts of plants & $\begin{array}{c}\text { Tribal of Wardha district of } \\
\text { Maharashtra }\end{array}$ & Decoction and juice & {$[5,11]$} \\
\hline 2 & $\begin{array}{l}\text { Acute and chronic } \\
\text { inflammations }\end{array}$ & Root & Korku tribe & Root extract & [15] \\
\hline 3 & Analgesic & Bark & Jalpaiguri/West Bengal & $\begin{array}{l}\text { The paste of bark has been } \\
\text { used for the relief of pain } \\
\text { especially for lower limbs. }\end{array}$ & [19] \\
\hline 4 & Anthelmintic & Fruits and seeds & $\begin{array}{c}\text { Asia and Australian } \\
\text { tropics/Pune (Maharashtra) }\end{array}$ & Decoction & {$[2,23]$} \\
\hline 5 & $\begin{array}{l}\text { Antidote to } \\
\text { vegetable poison }\end{array}$ & $\begin{array}{l}\text { Stem bark, leaves } \\
\text { and fruits }\end{array}$ & $\begin{array}{c}\text { Tropical Asia and Australian } \\
\text { tropics/Krishnagiri District, } \\
\text { Tamil Nadu, India }\end{array}$ & Unknown & {$[5]$} \\
\hline 6 & $\begin{array}{l}\text { Antivenom } \\
\text { (Vishaghna) }\end{array}$ & Leaves & Ayurveda & Unknown & [13] \\
\hline 7 & Aphrodisiac & Powder of flowers & $\begin{array}{c}\text { Tropical Asia and Australian } \\
\text { tropics/Krishnagiri District, } \\
\text { Tamil Nadu, India }\end{array}$ & $\begin{array}{l}\text { Powder of flowers } \\
\text { with milk has been } \\
\text { employed as } \\
\text { an aphrodisiac. }\end{array}$ & [5] \\
\hline 8 & Asthma & Leaves and bark & Garasia tribes/Rajasthan & $\begin{array}{l}\text { Decoction, juice of leaves } \\
\text { and bark juice. }\end{array}$ & [18] \\
\hline 9 & Astringent & Fruits & $\begin{array}{l}\text { Asia and Australian } \\
\text { tropics/Pune (Maharashtra) }\end{array}$ & Juice of fruits & {$[2,23]$} \\
\hline 10 & Blisters of mouth & Leaves & Remote areas of Rajasthan & $\begin{array}{l}\text { Powdered leaves were } \\
\text { chewed with equal } \\
\text { quantities of sugar. }\end{array}$ & {$[24,25]$} \\
\hline 11 & Cachexia & $\begin{array}{l}\text { Stem bark, leaves } \\
\text { and fruits }\end{array}$ & $\begin{array}{c}\text { Tropical Asia and Australian } \\
\text { tropics/Krishnagiri District, } \\
\text { Tamil Nadu, India }\end{array}$ & Unknown & [5] \\
\hline 12 & Cough and cold & Leaves and bark & Garasia tribes/Rajasthan & $\begin{array}{c}\text { Decoction of leaves and } \\
\text { bark juice. }\end{array}$ & [18] \\
\hline 13 & Cuts and wounds & Leaves & Garasia tribes/Rajasthan & $\begin{array}{l}\text { The leaves were grounded } \\
\text { and its paste is applied } \\
\text { topically on wounds. }\end{array}$ & {$[18,21]$} \\
\hline 14 & Delivery pain & Bark & Garasia tribes/Rajasthan & Bark juice & [18] \\
\hline 15 & Demulcent & Fruits & $\begin{array}{l}\text { Asia and Australian } \\
\text { tropics/Pune (Maharashtra) }\end{array}$ & Unknown & {$[2,23]$} \\
\hline 16 & Dental caries & Stems & Ayurveda & Bark is used as toothbrush & [26] \\
\hline 17 & Diabetes (Prameha) & Leaves & Ayurveda & Decoction & [13] \\
\hline 18 & Diarrhea & Bark and roots & Ayurveda & Decoction of bark and roots & [5] \\
\hline 19 & Diphtheria & Stems and bark & Ayurveda & $\begin{array}{l}\text { Decoction of stem and bark } \\
\text { for the treatment } \\
\text { of diphtheria. }\end{array}$ & [5] \\
\hline
\end{tabular}


Table 1. Cont.

\begin{tabular}{|c|c|c|c|c|c|}
\hline S. No. & Ailment/Use & Part of Plant & Locality/System of Medicine & Preparation Used & References \\
\hline 20 & Diuretic & Fruit & $\begin{array}{c}\text { Asia and Australian } \\
\text { tropics/Pune (Maharashtra) }\end{array}$ & Decoction & {$[2,23]$} \\
\hline 21 & Dysentery & Stem bark & $\begin{array}{l}\text { South West } \\
\text { Bengal/district-Dindori, } \\
\text { Madhyapradesh }\end{array}$ & $\begin{array}{l}\text { Stem bark powder has been } \\
\text { administered orally thrice } \\
\text { in a day for the treatment } \\
\text { of dysentery. }\end{array}$ & {$[27,28]$} \\
\hline 22 & Dysuria & Leaves & Kota district of Rajasthan & $\begin{array}{l}\text { Leaf powder was mixed } \\
\text { with sugar and divided into } \\
10 \text { equal doses. Each dose } \\
\text { has been administered daily } \\
\text { orally along with goat milk } \\
\text { or curd for cure of dysuria. }\end{array}$ & [25] \\
\hline 23 & Eczema & Leaves & $\begin{array}{c}\text { Tharu } \\
\text { community/Uttarakhand }\end{array}$ & $\begin{array}{l}\text { Paste of leaves } \\
\text { was applied topically for } \\
\text { the cure of eczema. }\end{array}$ & [21] \\
\hline 24 & Expectorant & Fruit & $\begin{array}{c}\text { Asia and Australian } \\
\text { tropics/Pune (Maharashtra) }\end{array}$ & Decoction & {$[2,23]$} \\
\hline 25 & Fever & Leaves & Garasia tribes/ Rajasthan & Decoction of leaves & [18] \\
\hline 26 & Fissure & Leaves & Wardha Tribe/Maharashtra & $\begin{array}{l}\text { Ghrit was prepared by } \\
\text { using fresh leaves and } \\
\text { applied locally on anal } \\
\text { fissure twice a day for } 21 \\
\text { days. Additionally, Triphala } \\
\text { Churna }(10 \mathrm{~g}) \text { has also been } \\
\text { recommended before bed } \\
\text { time for one month with } \\
\text { lukewarm water. }\end{array}$ & [17] \\
\hline 27 & Food and fodder & $\begin{array}{l}\text { Bark, leaves, stems } \\
\text { and fruits }\end{array}$ & $\begin{array}{c}\text { Tropical Asia and Australian } \\
\text { tropics/Krishnagiri District, } \\
\text { Tamil Nadu, India. }\end{array}$ & $\begin{array}{l}\text { Inner bark of E. laevis has } \\
\text { been used as food (dietary } \\
\text { supplement for humans } \\
\text { and cattle). Fruits are also } \\
\text { edible by tribal children. }\end{array}$ & {$[5,23]$} \\
\hline 28 & Fracture & Leaves & $\begin{array}{c}\text { Ayurveda/ } \\
\text { Garasia tribes/Rajasthan }\end{array}$ & $\begin{array}{l}\text { Kalka (paste) was prepared } \\
\text { and applied all over the } \\
\text { foot. Cotton pad and cotton } \\
\text { roll were applied firmly. } \\
\text { The thickness of Kalka was } \\
0.5-1 \mathrm{~cm} \text {. This Kalka Lepana } \\
\text { was kept for } 24 \text { h everyday } \\
\text { with dressing for } \\
\text { two weeks. }\end{array}$ & {$[14,18,29]$} \\
\hline 29 & Fungal infections & Leaves & $\begin{array}{c}\text { Dry deciduous forest areas of } \\
\text { Paschim Medinipur district, } \\
\text { West Bengal }\end{array}$ & $\begin{array}{l}\text { Paste of leaves } \\
\text { applied locally. }\end{array}$ & [30] \\
\hline 30 & Gum's problems & Stems & Dhule district/Maharashtra & $\begin{array}{l}\text { Brush with stem piece can } \\
\text { also be used. }\end{array}$ & [16] \\
\hline 31 & Headache & Roots and leaves & Ayurveda & $\begin{array}{l}\text { Paste of leaves } \\
\text { were applied. }\end{array}$ & [23] \\
\hline 32 & Joint pain & Leaves & $\begin{array}{c}\text { Tribal of Wardha district } \\
\text { of Maharashtra }\end{array}$ & Decoction and juice & [5] \\
\hline 33 & Liver ailments & Leaves and seeds & & Paste of seeds & [31] \\
\hline 34 & $\begin{array}{c}\text { Liver } \\
\text { diseases/jaundice }\end{array}$ & Seeds & $\begin{array}{l}\text { Gujjar tribes/Sub-Himalayan } \\
\text { region, Uttarakhand }\end{array}$ & $\begin{array}{c}\text { Paste of soaked seeds was } \\
\text { mixed with powder of } \\
\text { Amomum subulatum and } \\
\text { given with milk three times } \\
\text { a day. }\end{array}$ & [20] \\
\hline
\end{tabular}


Table 1. Cont.

\begin{tabular}{|c|c|c|c|c|c|}
\hline S. No. & Ailment/Use & Part of Plant & Locality/System of Medicine & Preparation Used & References \\
\hline 35 & $\begin{array}{l}\text { Manufacturing of } \\
\text { cosmetics, wines } \\
\text { and dyes }\end{array}$ & $\begin{array}{l}\text { Stem bark, leaves } \\
\text { and fruits }\end{array}$ & $\begin{array}{c}\text { Tropical Asia and Australian } \\
\text { tropics, Krishnagiri District, } \\
\text { Tamil Nadu, India }\end{array}$ & Unknown & {$[2,8,32]$} \\
\hline 36 & Ornamental pot herb & Whole plant & $\begin{array}{c}\text { Tropical Asia and Australian } \\
\text { tropics, Krishnagiri District, } \\
\text { Tamil Nadu, India }\end{array}$ & Grown in earthen pots & {$[2,8,32]$} \\
\hline 37 & Ringworm infections & Powdered kernel & Pune (Maharashtra) & $\begin{array}{l}\text { Powdered kernel was } \\
\text { mixed with oil and is } \\
\text { applied topically to the } \\
\text { affected area as a remedy } \\
\text { for ringworm infections. }\end{array}$ & {$[2,23]$} \\
\hline 38 & Scabies & Leaves & South West Bengal & Decoction and juice & [23] \\
\hline 39 & Skin diseases & Leaves & $\begin{array}{c}\text { Tharu } \\
\text { community/Uttarakhand }\end{array}$ & $\begin{array}{l}\text { The leaves were grounded } \\
\text { and its paste is } \\
\text { applied topically } \\
\text { on affected areas. }\end{array}$ & {$[21,33]$} \\
\hline 40 & Stomach diseases & $\begin{array}{l}\text { Stem bark, leaves } \\
\text { and fruits }\end{array}$ & $\begin{array}{c}\text { Tropical Asia and Australian } \\
\text { tropics/Krishnagiri District, } \\
\text { Tamil Nadu, India }\end{array}$ & $\begin{array}{l}\text { Decoction of leaves } \\
\text { and barks. }\end{array}$ & [5] \\
\hline 41 & Syphilis & Bark and roots & Ayurveda & $\begin{array}{l}\text { Decoction of bark } \\
\text { and roots. }\end{array}$ & {$[5,34]$} \\
\hline 42 & Throat infections & Bark & $\begin{array}{l}\text { Tropical Asia and } \\
\text { Australian tropics }\end{array}$ & $\begin{array}{c}\text { Bark is used internally and } \\
\text { as a gargle in } \\
\text { throat infections. }\end{array}$ & [23] \\
\hline 43 & Toothache & Young branches & Pawra Tribe of Satpura Hills. & $\begin{array}{l}\text { Young branches are used } \\
\text { as toothbrushes. }\end{array}$ & {$[5,35]$} \\
\hline 44 & Malaria and fever & Leaves & $\begin{array}{l}\text { Tribe of Andaman \& } \\
\text { Nicobar Islands }\end{array}$ & Decoction of leaves & [36] \\
\hline 45 & Ulcers & Stem & Dhule district/Maharashtra & Paste of leaves & [16] \\
\hline 46 & $\begin{array}{l}\text { Urinary tract } \\
\text { infections }\end{array}$ & Bark and roots & & Decoction of bark and roots & {$[5]$} \\
\hline 47 & Venereal diseases & Bark and roots & Ayurveda & $\begin{array}{l}\text { Decoction of bark and roots } \\
\text { have been recommended. }\end{array}$ & {$[5,11,34,37]$} \\
\hline
\end{tabular}

\section{Phytochemistry}

Ethnobotanical studies established that barks, leaves and fruits of E. laevis are potential sources of phytoconstituents. Phytochemical investigations had led to the extraction and isolation of secondary metabolites along with primary metabolites from petroleum ether, chloroform and methanolic extracts of its barks and leaves. These are pentacyclic triterpenoids, flavonoids, alkaloids, tannins, phenolic components, phenolic acids, hydrocarbons, aliphatic alcohols, fatty acids, ascorbic acid, amino acids, carbohydrates, benzoquinones, vitamins and minerals [6-9,34,38-41].

\subsection{Pentacyclic Triterpenoids and Phytosterol}

Pentacyclic triterpenes are abundantly found in medicinal plants and they are synthesized in the cytosol from the cyclization of an epoxidized squalene which is a precursor of the diverse group of polycyclic triterpenes. Terpenes are derived from $\mathrm{C}_{5}$ isoprene units, and based on the number of isoprene units, terpenes are classified according to the number of carbon atoms in the polycyclic chain $\left(C_{n}\right)$ into; hemiterpenes $\left(C_{5}\right)$ monoterpenes $\left(C_{10}\right)$, sesquiterpenes $\left(C_{15}\right)$, diterpenes $\left(C_{20}\right)$, sesterterpenes $\left(C_{25}\right)$, triterpenes $\left(C_{30}\right)$ and tetraterpenes $\left(\mathrm{C}_{40}\right)$. Triterpenoids are either acyclic (only chains without rings or cycles) and pentacyclic (forming five rings or cycles). The pentacyclic triterpenes can be divided into three main classes, depending on the scaffold of their architecture, into; lupane (e.g., betulinic acid, betulin, lupeol) oleanane (e.g., $\beta$-amyrin) and ursane (e.g., $\alpha$-amyrin, ursolic 
acid), etc. Presently, pentacyclic triterpenes have received much attention because of their versatile biological activities. Pentacyclic triterpenoids are the main active constituents present in its bark and leaves of E. laevis. Joshi and Wagh, reported a GC-MS analysis to isolate the triterpenoids such as lupane (1), olenane (2), ursane (3), betulinic acid (4), betulin (5), lupeol (6), ursolic acid (7) $\alpha$-amyrin (8), $\beta$-amyrin (9), bauerenol (10), bauerenol acetate (11) and $\beta$-sitosterol (12) from petroleum ether, chloroform and methanolic extracts of its barks and leaves. The structures of most promising triterpenoids are presented in Figure 2. These compounds display various pharmacological actions, and are generally devoid of major toxicity. Therefore, these triterpenes have become the promising leading compounds for the scientific community to design new multi-targeting bioactive agents $[9,38]$.

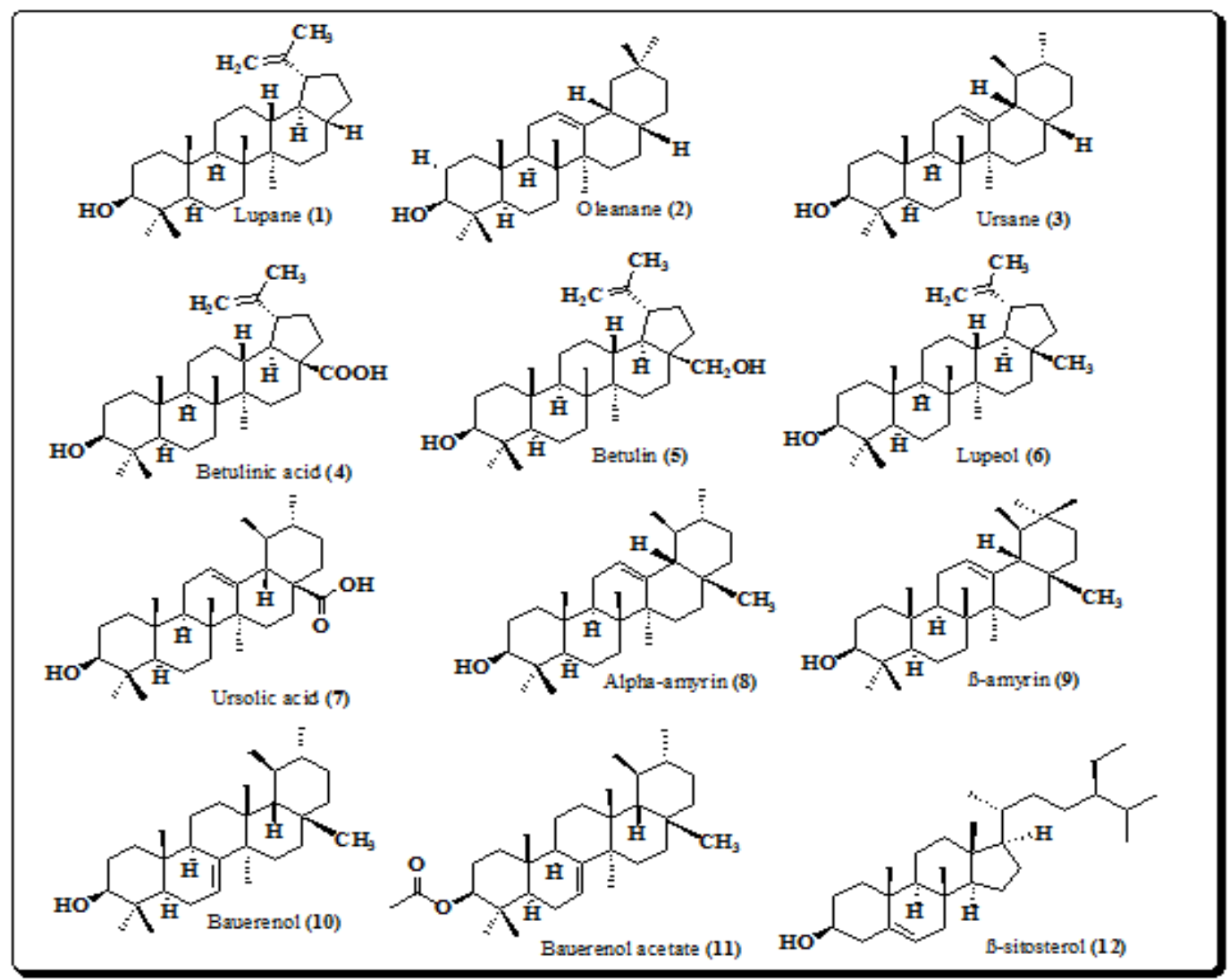

Figure 2. Structures of pentacyclic triterpenoids and phytosterol from E. laevis (1-12).

\subsubsection{Betulinic Acid}

Betulinic acid (BA, 3ß-hydroxy-lup-20(29)-en-28-oic acid), widely distributed throughout the plant kingdom, is a well known pentacyclic lupane-type triterpenoid natural moiety which has gained a lot of attention because of its broad range of pharmacological properties, e.g., antimalarial [42], anti-inflammatory [43], antinociceptive [44], antibacterial [45] and anticancer activities [46]. Besides BA is known to inhibit the growth of canine cancer cell lines and cell arrest in the S-phase of the cell cycle, with an $\mathrm{IC}_{50}$ value of $23.5 \mu \mathrm{M}$ in CL-1 cell line $[47,48]$.

\subsubsection{Betulin}

Betulin (3ß-lup-20(29)-ene-3, 28-diol) is the reduced congener of betulinic acid. It was the first natural moiety isolated from bark of the white birch Betula alba in 1788 and its chemical structure was determined in 1952. Betulin exhibits various pharmacological activities, e.g., antimicrobial [49,50], anti-inflammatory and antitumor activities [51]. It has been established that betulin is as potent as betulinic acid towards the CL-1 cell line with 
$\mathrm{IC}_{50}$ value of $27.0 \mu \mathrm{M}$ and is one of the selective anticancer agents against various human cancer cell lines, e.g., lung cancer, melanoma and lymphoma cells [48,52,53].

\subsubsection{Lupeol}

Lupeol (lup-20(29)-en-3 $\beta$-ol) is abundantly found in medicinal plants and has been reported to possess an array of pharmacological activities, including antiangiogenic [54], anti-inflammatory [55], anticancer, antiarthritis, antidiabetic, cardiovascular [56-58] and antioxidant activities [59]. Lupeol is one of the potential anticancer biomarkers. It has been investigated that lupeol exhibits anticancer activity against human osteosarcoma cells. It induces apoptosis and cell cycle arrest in G0/G1 phase along with down regulation of PI3-Kinase [59].

\subsubsection{Ursolic Acid}

Ursolic acid (3ß-hydroxy-urs-12-ene-28-oic acid) is a well known pentacyclic terpenoid of plant origin exhibiting a wide range of pharmacological activities, e.g., antiviral [60], antiulcerosos [61], anti-inflammatory and anticancer activities [62].

\subsection{5. $\alpha$-Amyrin}

$\alpha$-Amyrin ( $3 \beta$-hydroxy-urs-12-en) is the precursor of ursolic acid and predominantly found in plant origin, exhibiting an array of pharmacological activities, e.g., anxiolytic, antidepressant [63], anti-inflammatory [64,65], antihyperglycemic and hypolipidemic activities [66]. When administered in a dose of $30 \mathrm{mg} / \mathrm{kg}$ to animals, the compound significantly reduced inflammation caused by partial sciatic nerve ligation along with thermal and mechanical hyperalgesia, proving that $\alpha$-amyrin could be a potential molecule for the relief of pain and inflammation. The compound exerts its extended antinociceptive action through activation of cannabinoid receptors [67].

\subsection{6. $\beta$-Amyrin}

The triterpene $\beta$-amyrin ( $3 \beta$-hydroxy-olean-12-en) has shown various pharmacological activities, e.g., antioxidant, anti-inflammatory, analgesic [65], antihyperglycemic and hypolipidemic [66] activities. $\beta$-amyrin is also known to exhibit anxiolytic and antidepressant, antimicrobial and antifungal actions [63,68-70]. The triterpene $\beta$-a both $\alpha$ and $\beta$-amyrins are known to minimise the IL- 6 , TNF- $\alpha$ and IL- $1 \beta$ levels along with the myeloperoxidase activity [71].

\subsection{7. $\beta$-Sitosterol}

The physterol $\beta$-sitosterol ( $3 \beta$-stigmast-5-en-3-ol) is one of the important active principles of many plants. It is also used as one of the potential plant biomarkers for the treatment and prevention of cancer [59]. The compound acts by inducing apoptosis and activating caspases such as caspase- 3 and caspase-9, with an $\mathrm{IC}_{50}$ value of $16 \mu \mathrm{M}$ in human breast cancer cell lines (MDA-MB-231) [72].

\subsection{Flavonoids}

Flavonoids are a group of natural products, which are ubiquitously present in plants (fruits, vegetables and also in certain beverages) [73]. They are associated with various therapeutic activities and are present in a variety of medicinal, nutraceutical, pharmaceutical, and cosmetic preparations. The basic structures of these compounds are often characterized by a fifteen-carbon skeleton as a common phenyl benzopyrone linkage $\left(C_{6}-C_{3}-C_{6}\right)$ in their structures [74]. Flavonoids are a promising class of natural products sub-divided into flavonols (quercetin and kaempferol), flavones (luteolin and apigenin), flavanones (hesperetin and naringenin), flavan-3-ols (catechin and epicatechin) isoflavones (genistein), and flavanones [13,74-76]. Structures of flavonoids from the plant (13-30) are shown in Figure 3. 


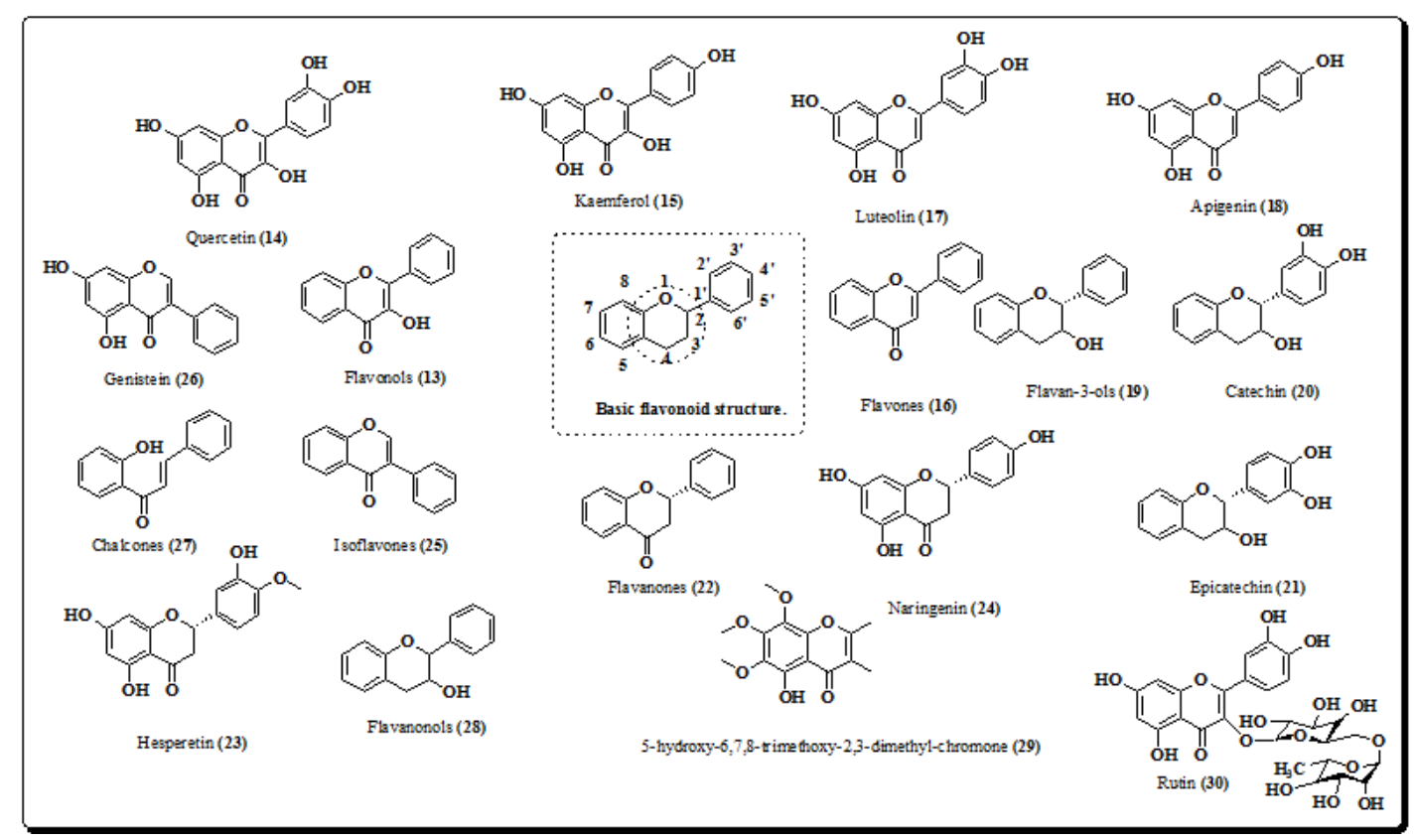

Figure 3. Structures of flavonoids from E. laevis. (13-30).

Flavonoids exert diverse activities, e.g antimycobacterial [77], antioxidant [78], antiinflammatory [79], anticancer [80-82] and antimalarial [83]. Phytochemical screening of methanolic extracts of E. laevis indicates the presence of flavonoids [9,10]. The main bioactive molecules isolated from methanolic and its leaf and bark chloroform extracts are flavonoid glycosides. The total flavonoid contents of the plant were determined using the aluminium chloride method [84]. It was also reported that flavonoids (57.23 mg equivalent to rutin (RE)/g) were present in the methanolic extracts of the plant [8]. A quantitative determination of flavonoids isolated from extracts of E. laevis using aluminium chloride colorimetric methods showed the presence of rutin and quercetin [10]. The compound 5hydroxy-6,7,8-trimethoxy-2,3-dimethyl-chromone (29) was isolated from the ethyl acetate: formic acid: glacial acetic acid: water fraction [2].

\subsubsection{Quercetin}

Quercetin $\left(3,3^{\prime}, 4^{\prime}, 5,7\right.$-pentahydroxyflavanone) is a citrus polyphenolic flavonoid abundantly present in vegetables and fruits, e.g., black grapes, onion and tea $[85,86]$. It was the first known tyrosine kinase inhibitor in the phase-I human clinical trials $[87,88]$. Recent studies have reported for its broad spectrum of activities, including against cancer, cardiovascular diseases, inflammatory and CNS disorders [89,90]. Quercetin exhibits its significant antioxidant activity by sustaining oxidative balance [91]. Antioxidant actions of quercetin are manifested due to its effect on signal transduction, reduced glutathione (GSH) and reactive oxygen species. Quercetin enhances the antioxidant capability of the body by regulating the levels of GSH. It has also been reported that the oral administration of tamoxifen with quercetin encapsulated in nano-particles formulation considerably induces apoptosis and thus attenuating the growth of breast cancer $[92,93]$.

\subsubsection{Kaempferol}

Kaempferol (3,4',5,7-tetrahydroxyflavone) belongs to the flavonol class of flavonoid. It is abundantly found in tea, beans, apple, strawberries and spinach [94-96]. Recently, numerous investigations established its diverse pharmacological activities, e.g., cardioprotective [97], hepatoprotective [98], anti-inflammatory [99], antioxidant [100], anticancer [101], neuroprotective [102] and antidiabetic properties [103]. Kaempferol was found to be effective against various types of cancers, including skin, colon and hepatic cancer [104,105]. It also has the tendency to scavenge the generation of free radicals viz., hydroxyl, superox- 
ide anions, peroxides and nitric oxide. The anti-inflammatory action of kaempferol has been established in both in vitro and in vivo, and it is known to be via the inhibition of lipopolysaccharide (LPS) and adenosine triphosphate (ATP) and by influencing phosphorylation of AKT and PI3K in cardiac fibroblasts, and thus shielding cells from inflammatory damage [106].

\subsubsection{Luteolin}

Luteolin $\left(3^{\prime}, 4^{\prime}, 5,7\right.$-tetrahydroxyflavone) is a flavone present in a wide variety of fruits, vegetables and in medicinal plants $[107,108]$. Vegetables including celery, parsley, onion leaves, broccoli, peppers and carrots are rich in luteolin [108]. Luteolin shows an array of biological properties, including antioxidant [109], antimicrobial [108], anticancer [110] and estrogenic regulator properties [111]. Luteolin has the ability to induce apoptosis and produce anticancer effects by causing cell cycle arrest in human oral squamous cancerous cells, human esophageal, colon, lung and liver cancers [112-114]. Luteolin also induces apoptosis and inhibits proliferation against human prostate cancer cells in xenografts models [115]. It acts through various mechanisms in cancer including invasion, cell cycle arrest or metastasis by reduction of transcription factors, inhibition of kinases and induction of cell death via apoptosis [116].

\subsubsection{Apigenin}

Apigenin (4',5,7-trihydroxyflavone) is predominantly found in everyday diet. Out of all the classes of flavonoids, apigenin is ubiquitous in the plant kingdom. It is rich in tea, oranges, onion, celery, parsley, beer and wines [117]. Apigenin attracts researchers and has been recommended in nutraceuticals because of its numerous benefits and low toxicity [118]. Apigenin exhibits a broad spectrum of activities and is used in the cure of amnesia, depression, stroke, diabetes and cancer $[119,120]$. Numerous in vitro and in vivo studies support the therapeutic potential of apigenin as antioxidant, anti-inflammatory and anticancer [120]. It induces apoptosis by activating caspase-3, release of cytochrome-C in cytoplasm, reduction of mitochondrial membrane potential loss [121,122]. Antidepressant and neuroprotective effects of apigenin were observed, as well as its intervention on lipopolysaccharide (LPS) induced depressive-like behavior in animal models of mice [123]. The antidiabetic action of this compound has been established due to its ability to inhibit the $\alpha$-glucosidase activity, resulting in increased release of insulin [124]. Apigenin also exhibits its anti-HIV activity in T-cell line (H9) contaminated with HIV-I and HIV-1 (IIIB) [125-127].

\subsubsection{Naringenin}

Naringenin [5,7-dihydroxy-2-(4-hydroxyphenyl)chroman-4-one] belongs to the flavanone series of flavonoids and is predominantly found in citrus fruits like oranges, lemons, grapes and tomatoes. It is a common polyphenolic dietary component and is derived from the hydrolysis of narirutin or naringenin-7-rutinoside $[128,129]$. The scientific community pays considerable attention to this flavonoid because of its therapeutic potential, including its antioxidant [130], antidiabetic [131], and anti-inflammatory properties [132] and potential against malignancies and neurodegenerative diseases [133,134]. Naringenin exerts its antioxidant effects by scavenging free radical generation and enhancing several antioxidant enzyme levels such as glutathione peroxidase, catalase and superoxide dismutase [135]. It also has potential anticancer properties against breast cancer MDA-MB-231 cell lines by inhibiting HER2-TK activity, in prostate cancer by mitochondrial membrane potential loss, and in liver cancer via activation caspase-3 and induction of apoptosis [136-139]. Naringenin also exhibits antidiabetic activity in vitro at a dose of $5 \mu \mathrm{g}$ and in vivo at the dose of $50 \mathrm{mg} / \mathrm{kg}$ by decreasing the glucose level [140,141].

\subsubsection{Rutin}

Rutin ( $3^{\prime}, 4^{\prime}, 5,7$-tetrahydroxyflavone-3-rhamnoglucoside) is abundantly available as a flavonol of plant origin. The compound is abundantly present in fruit skin, buckwheat 
and potato skin of this plant [142]. It exhibits various pharmacological activities including neuroprotective [143], cardioprotective [144], antidiabetic [145], anticarcinogenic [146], anti-inflammatory [145], and antioxidant [146-151]. It scavenges free radicals and inhibits the lipid peroxidation [152,153]. It is also reported to act as a hepatoprotective agent [154].

\subsection{Phenolic Acids and Tannins}

Plant phenolic acids are a fundamental human dietary component and are well renowned for their pharmacological actions such as antioxidant [155], anticancer [156], antiallergic [157], antimicrobial [157] and anti-inflammatory properties [157,158]. The antioxidant potential of a particular phenolic acid depends on the number of hydroxyl groups present as well as their position on the molecule. Tannins belong to the class of polyphenols. Tannins are water soluble compounds, are present in many plants and have the ability to precipitate proteins [159-161]. Polyphenols are considered to be significant antioxidants and also act as therapeutic candidates in the mitigation of many diseases. Gallic acid and tannic acid are the main phenolic acids present in leaves and stem bark of this plant $[8,84,162]$.

\subsubsection{Gallic Acid}

Gallic acid (3,4,5-trihydroxybenzoic acid) is a naturally-occurring plant phenol obtained by the hydrolysis of tannins. Gallic acid (31) is known for its diverse biological activities such as, hepatoprotective [163], anticancer [164], antimicrobial [165] and gastrointestinal disorders $[166,167]$. Oxidative stress results in an accumulation and overproduction of free radicals, and is the foremost origin of several degenerative diseases such as cardiovascular system (CVS) diseases [167], atherosclerosis [166], cancer [164] and inflammatory diseases [168]. Gallic acid (Figure 4) is a low molecular weight compound readily available in fruits, vegetables and medicinal plants. It has the ability to induce apoptosis and also acts as a strong antioxidant. It has been found in the methanolic extract of leaves of E. laevis $[8,157,158]$.

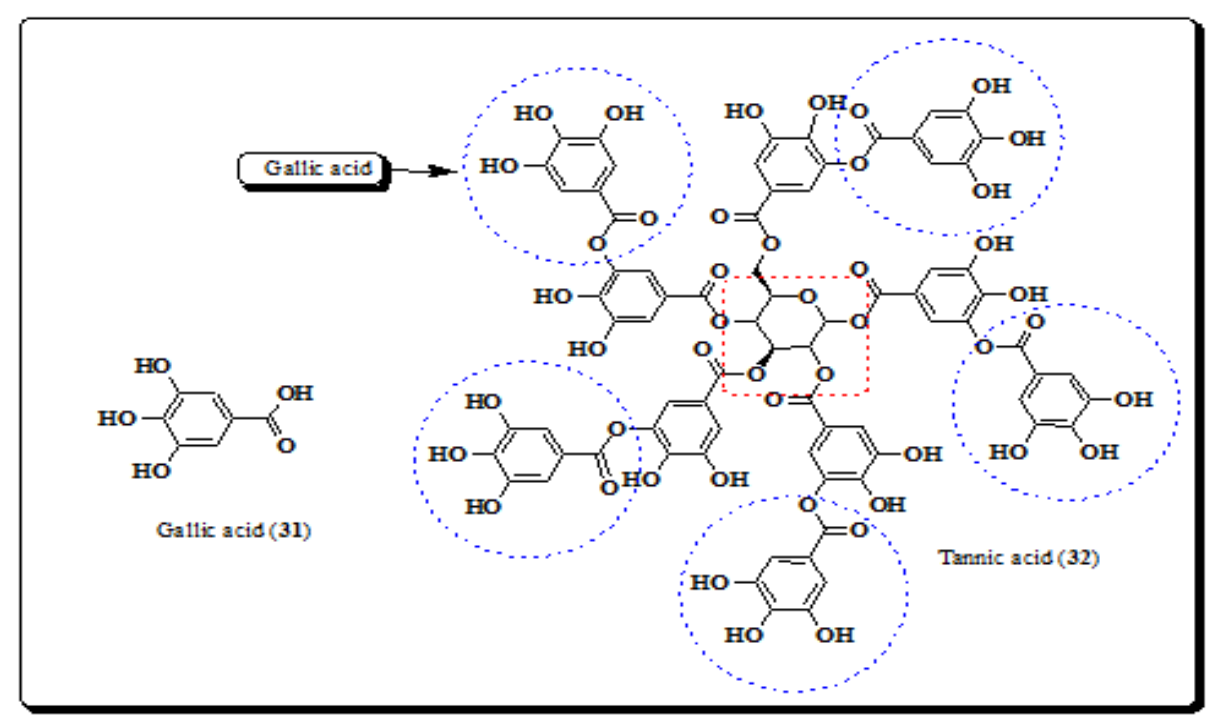

Figure 4. Structures of polyphenolic compounds from E. laevis. $(31,32)$.

\subsubsection{Tannic Acid}

Tannic acid (1,2,3,4,6-penta-O-\{3,4-dihydroxy-5-[(3,4,5-trihydroxybenzoyl)oxy] benzoyl\}]D-glucopyranose) (32) is a polyhydroxy phenol, whose structure contains a large number of phenol units, Figure $4[169,170]$. The phytochemical investigation of the stem bark and leaves of E. laevis reported the existence of tannic acid, along with other phytoconstituents in noticeable quantities. Rangnathrao and Shanmugasundar identified tannic acid by preliminary phytochemical screening of methanolic extracts of the stem bark of E. laevis 
and showed that this contains a high concentration of tannins, $64.12 \mathrm{mg}$ of tannic acid equivalent (TAE)/g $[8,10]$.

\subsection{Amino Acids}

Amino acids are the building blocks or basic units of proteins, which compose the foremost part of our body weight. They play an important role in our body since they are essential for vital processes such as synthesis of neurotransmitters and hormones [171]. Velappan and Thangaraj established the amino acid profiles of edible parts of E. laevis and compared it with reference levels of amino acids [8,172], showing that methionine (33), cysteine (34) and lysine (35) are most abundant amino acids of barks and leaves of E. laevis, whereas fruits are rich in tryptophan (36), leucine (37) and isoleucine (38). Additionally, asparagine (39), valine (40), histidine (41), glutamic acid (42), and threonine (43) were presented in traces [8,172]. The chemical structures of the identified amino acids are represented in Figure 5.

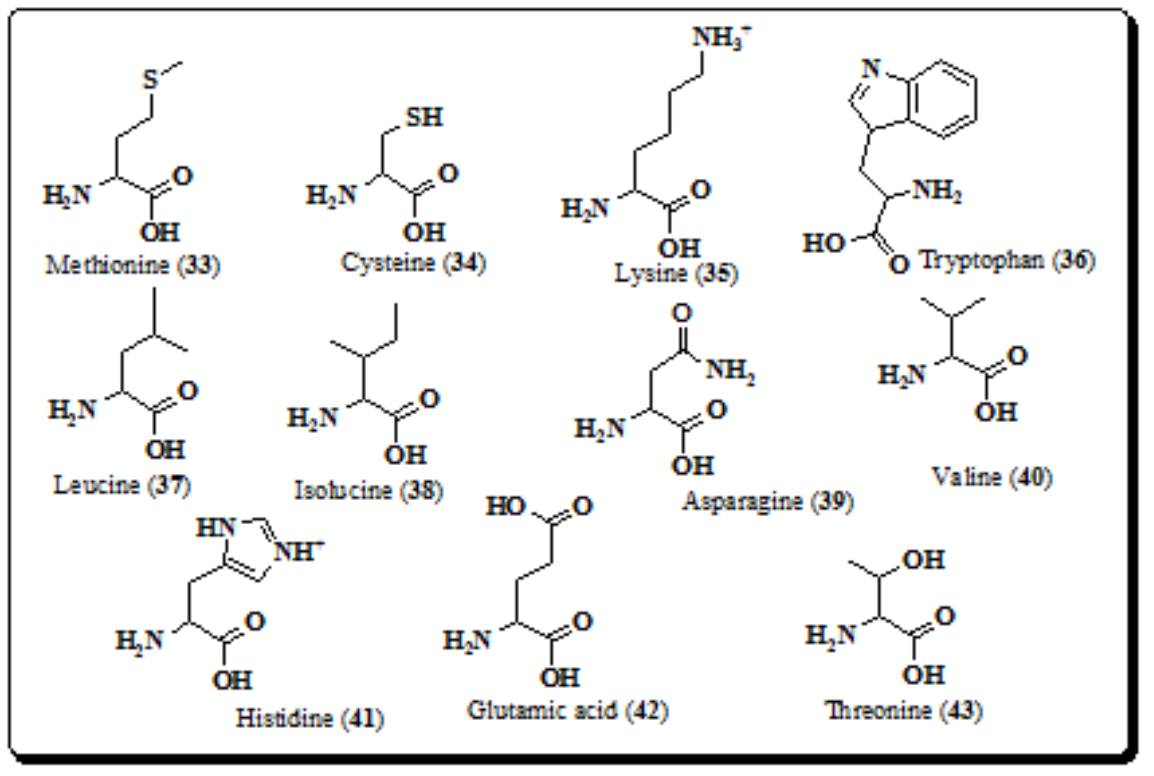

Figure 5. Structures of amino acids from E. laevis. (33-43).

\subsection{Carbohydrates}

The phytochemical investigation of the stem bark and leaves of E. laevis revealed the presence of primary metabolites such as carbohydrates in an appreciable quantity. Three carbohydrates (Figure 6) namely lactose (44), D-mannitol (45) and maltose (46) (Figure 6) were identified from the leaves [6,173-175].

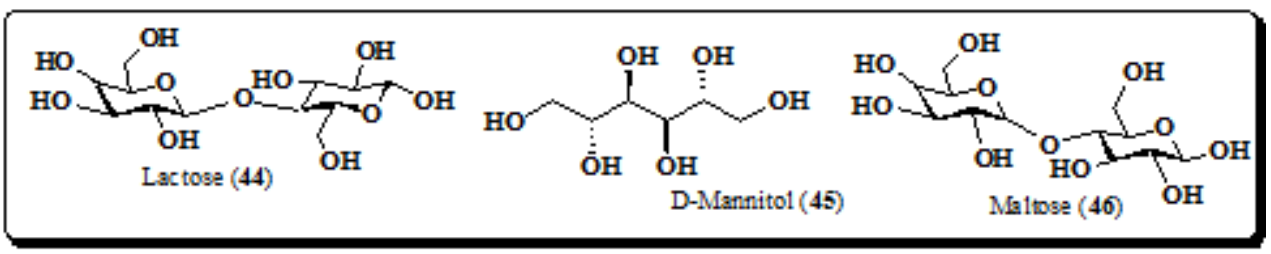

Figure 6. Structures of carbohydrates from E. laevis (44-46).

\subsection{Vitamins}

Literature on the quantitative assessment of trace elements in the leaves of E. laevis establish its nutritional value due to the presence of minerals and vitamins such as vitamins C, E, A, riboflavin and thiamine (47-51), Figure 7 [22,34]. Vitamin C plays a significant role 
in slowing the development and prevention of several diseases by exhibiting antioxidant action by scavenging free radicals and also acting as an enzyme cofactor in cells [176-181].

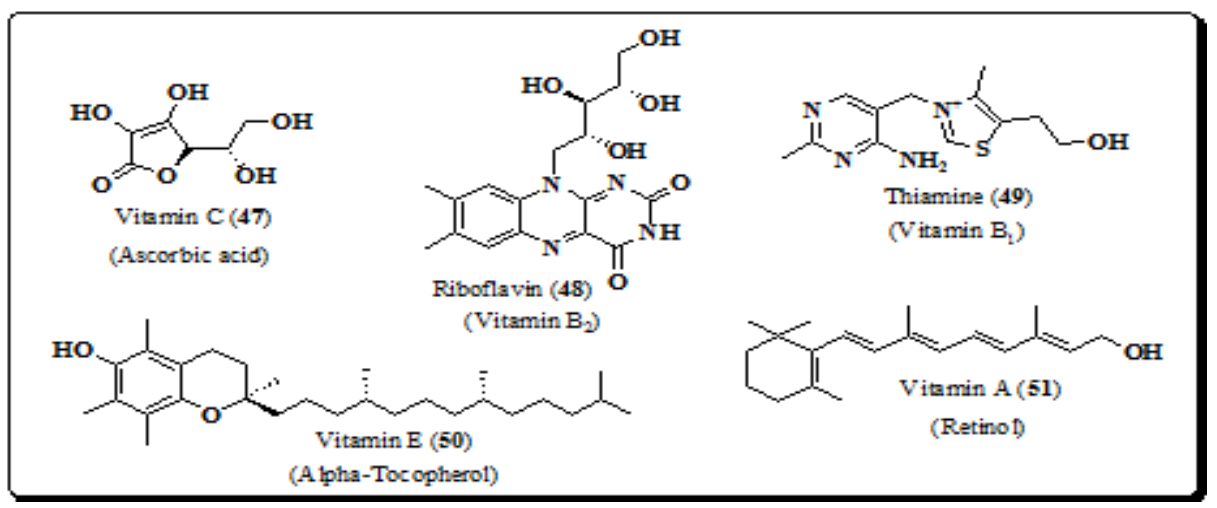

Figure 7. Structures of vitamins from E. laevis (47-51).

\subsection{Minerals}

Minerals are one of the essential and vital components of food and fodder. All the minerals play an important role in the structural and metabolic activities of the body, e.g., brain development, gastrointestinal tract (GIT) functions, bone development, bones and teeth strength. The fruits and inner bark of E. laevis are reported to be edible [32,182]. Experimental analysis of the bark, fruits and leaves of E. laevis confirmed the presence of a significant amount of minerals (Table 2), e.g., sodium $(2.12 \mathrm{~g} / \mathrm{kg})$, phosphorous $(7.36 \mathrm{~g} / \mathrm{kg}$ ) and calcium $(38.31 \mathrm{~g} / \mathrm{kg}$ ) found to be abundant in the leaves, while a few minerals like silica $(5.21 \mathrm{~g} / \mathrm{kg})$, copper $(0.05 \mathrm{~g} / \mathrm{kg})$ and zinc $(3.16 \mathrm{~g} / \mathrm{kg})$ were obtained from stem bark. The fruits of $E$. laevis were found to have notably high quantities of potassium $(28.12 \mathrm{~g} / \mathrm{kg})$, manganese $(0.04 \mathrm{~g} / \mathrm{kg})$, magnesium $(13.45 \mathrm{~g} / \mathrm{kg})$, and iron $(1.28 \mathrm{~g} / \mathrm{kg})[8,13,183]$.

Table 2. Composition of minerals from different parts of E. laevis.

\begin{tabular}{ccccc}
\hline S. No. & Mineral $(\mathbf{g} / \mathbf{K g})$ & Leaf & Bark & Fruit \\
\hline 1 & Sodium & 2.12 & 1.59 & 1.09 \\
2 & Phosphorous & 7.36 & 4.12 & 3.45 \\
3 & Calcium & 38.31 & 38.03 & 36.12 \\
4 & Zinc & 0.18 & 3.16 & 0.21 \\
5 & Potassium & 26.23 & 22.33 & 28.12 \\
6 & Iron & 1.11 & 0.30 & 1.28 \\
7 & Magnesium & 12.21 & 6.46 & 13.45 \\
8 & Copper & 0.02 & 0.05 & 0.01 \\
9 & Manganese & 0.03 & 0.02 & 0.04 \\
10 & Silica & 3.12 & 5.21 & 1.19 \\
\hline
\end{tabular}

\subsection{Miscellaneous}

Other minor compound classes like 1,4-naphthoquinone, dioctyl phthalate, aliphatic hydrocarbons, fatty acids, esters and benzofurans have also been isolated from different extracts of E. laevis. Lewisone (1,4-naphthoquinone, 52) is one of the important benzoquinones involved in the synthesis of vitamin K (Figure 8). Compound $\mathbf{5 2}$ is a new naphthoquinone from the aerial parts of $E$. laevis and showed significant antibacterial, antifungal, antiviral and anti-inflammatory properties [41]. Several other compounds, e.g., dioctyl phthalate (53), octylcyclohexane (54), decyl cyclohexane (55), hexadecane (56), heptadecane (57), tridecene (58), dodecane (59), tetradecane (60), nonadecane (61), tridecanol (62) and tetratetracontane (63), shown in Figure 8, have also been isolated from the bark of E. laevis [8,41]. 


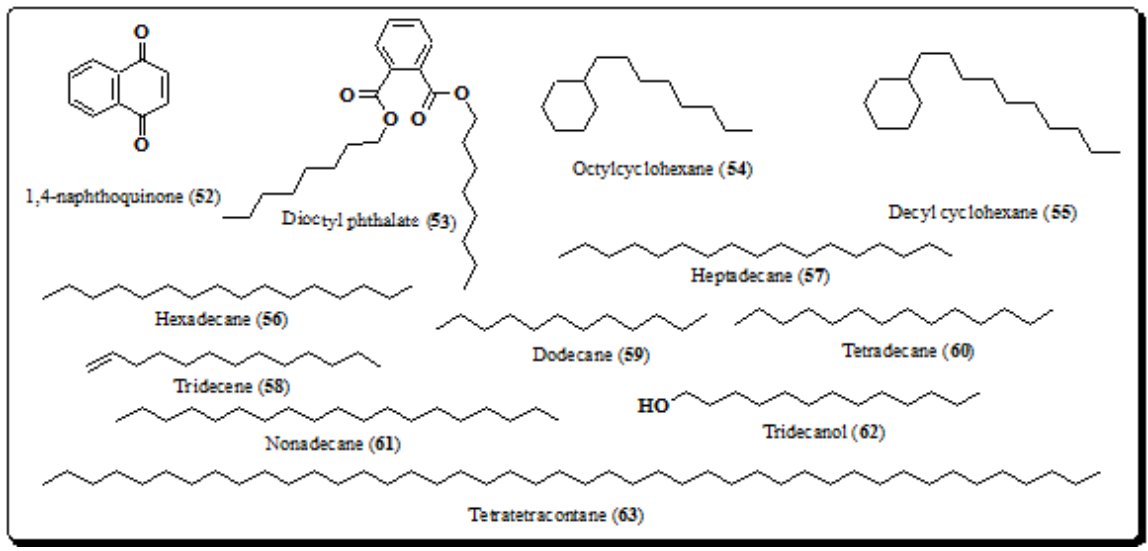

Figure 8. Structures of other compounds from E. laevis (52-63).

Some of the bioactive constituents have also been isolated from methanolic extract from the bark of E. laevis. The structures of isolated compounds are methyl ester of 2-trimethylsiloxy-6hexadecenoate (64), trimethylsilyl-eicosa-5,8,11,14-tetranoate (65) and 4-(dimethylaminomethyl5-hydroxybenzofuran-3-yl)(4-methoxyphenyl) methanone (66), Methyl-14-methylhexadecanoate (67), Methyl-4,7,10,13,16,19-docosahexaenoate (68), Phthalic acid, butyl oct-3-yl ester (69), Z,Z4,16-octadecadien-1-ol acetate (70) and 9-(ethoxymethyl)-heptadeca-2,15-diene (71), Figure 9 [9].

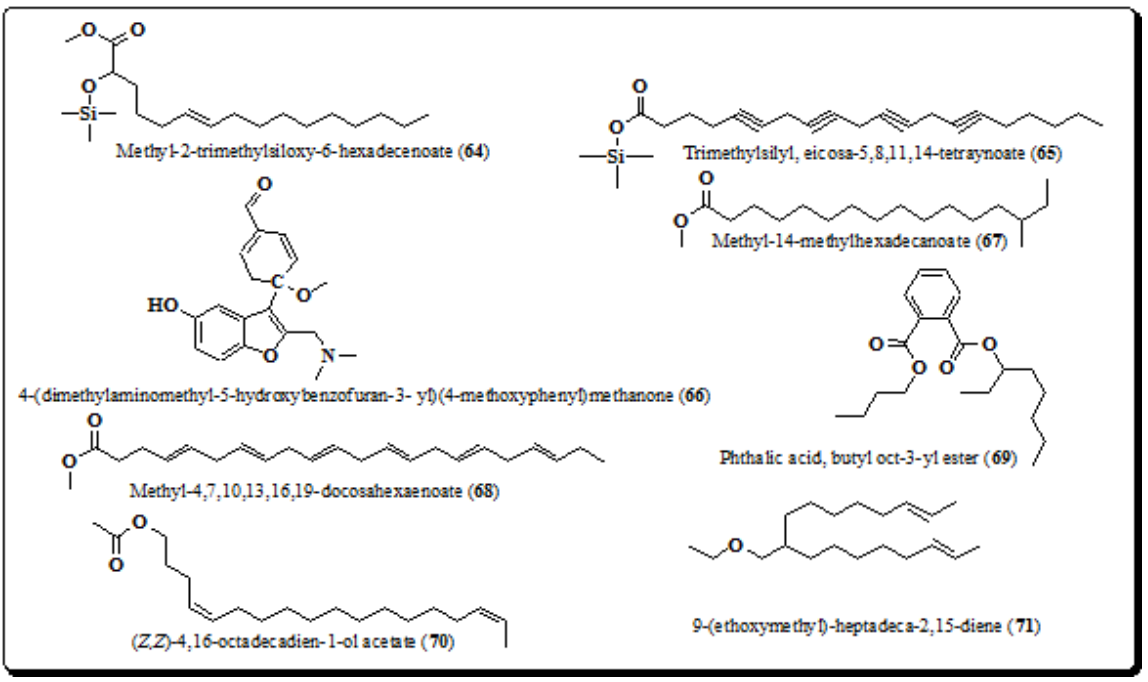

Figure 9. Structures of compounds from E. laevis (64-71).

Joshi and Wagh identified fifteen compounds, including hexadecyl-oxirane (72), phthalic acid, octyl 2-propylpentyl ester (73), 9-eicosyne (74), methyl-6,10-octadecadienoate (75), 3,7,11,15-tetramethyl-2-hexadecen-1-ol (76), hexadecamethyl-cyclooctasiloxane (77), (Z,Z,Z)-9,12,15-octadecatrienoic acid (78), dodecamethyl-cyclohexasiloxane (79), isobutyl octadecyl ester (80), 2,4-bis-(1,1-dimethylethyl)phenol (81), 1,2-dichloro-2-methyl-propane (82), 1-chloro-2-ethoxy-2-methoxy-propane (83), octyl ester of 1,2-benzenedicarboxylic acid (84), 4-chloro-2,4-dimethylhexane (85) and tetradecamethyl-cycloheptasiloxane (86) (Figure 10) from chloroform extract of bark of the plant $[9,184]$. 


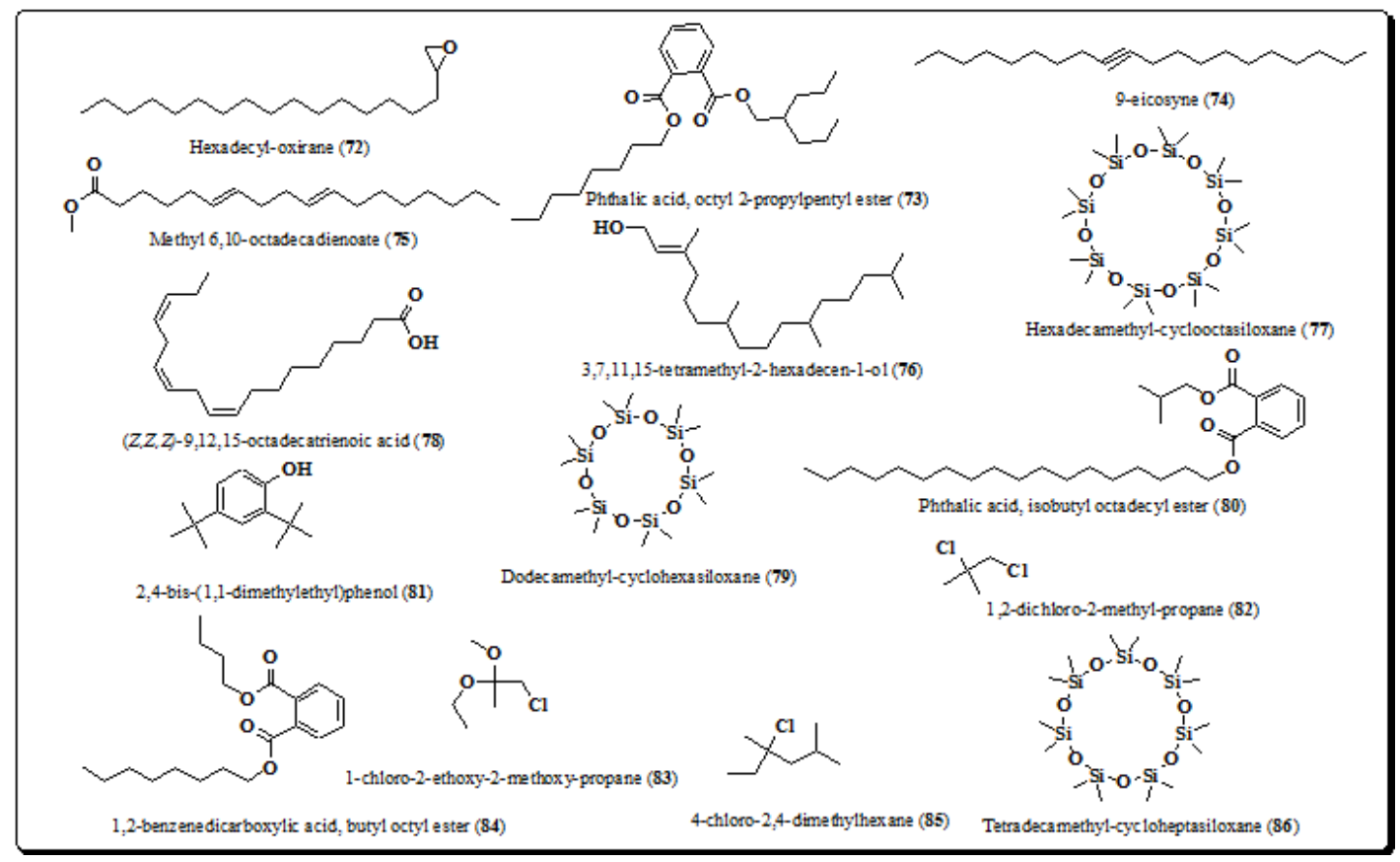

Figure 10. Structures of compounds from E. laevis (72-86).

Furthermore, using GC-MS profiling analysis established the structure of long chain aliphatic esters, alcohols, ketones, carboxylic acids and various other compounds (Figure 11), from petroleum ether extract of bark of the plant. These include 6,10,14-trimethyl-2-pentadecanone (87), (12E,15E)-methyl octadeca-12,15-dienoate (88), 2-(4-chlorophenylsulfonyl)-3-cyclohexylaminopropenenitrile (89), 5,6,7,7a-tetrahydro-4,4,7a-trimethyl-2(4H)-benzofuranone (90), methyl8,11,14-heptadecatrienoate (91), 3,7,11,15-tetramethyl-2-hexadecen-1-ol (92), methyl octadeca8,11-dienoate (93), 6,10,14-trimethyl-2-pentadecanone (94), 1,2-15,16-diepoxyhexadecane (95), tridecanoic acid (96), 15-methylhexadecanoate (97) and 2-hydroxy-octadeca-9,12,15trienoate $(\mathbf{9 8})[185,186]$.

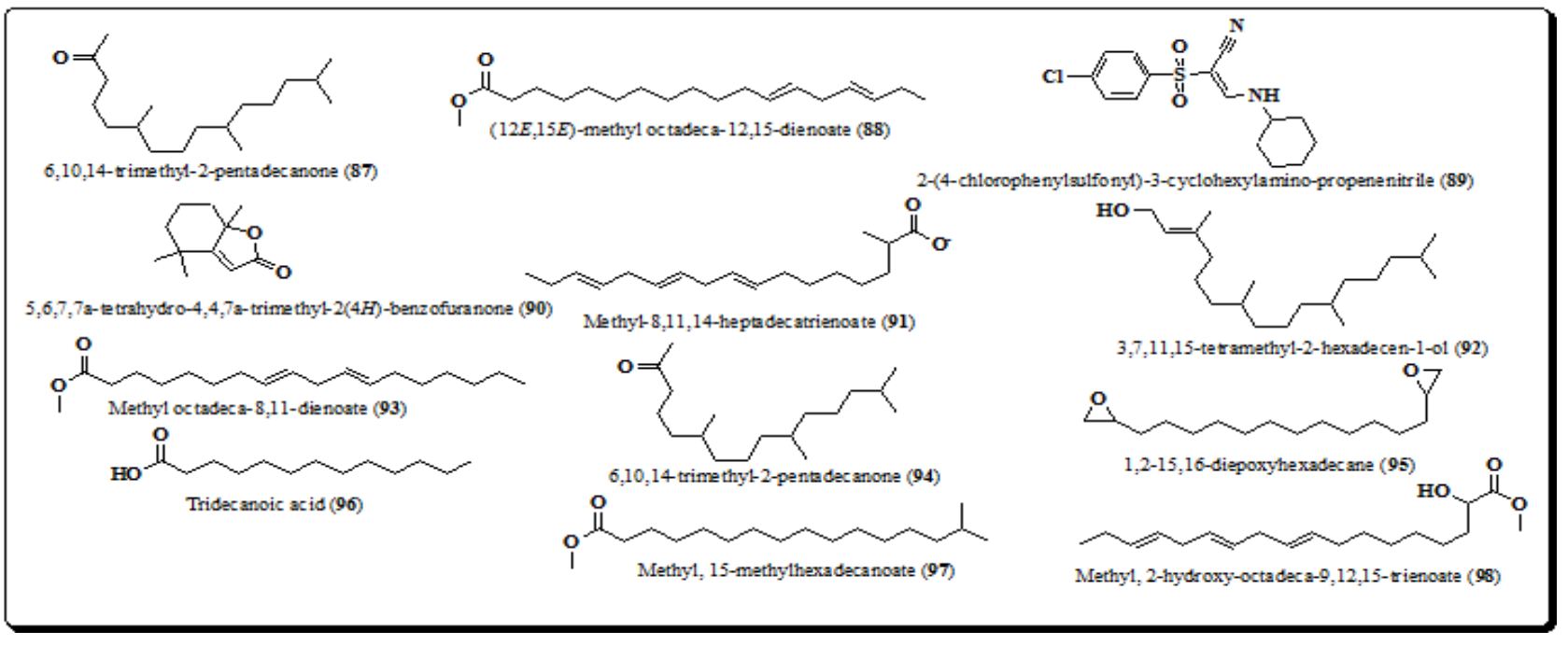

Figure 11. Structure of other compounds from E. laevis (87-98).

A variety of carbohydrates, proteins, minerals, amino acids and vitamins are present in E. laevis, making the plant good for food and fodder. Ripe fruits of plants are eaten by local children [187-190]. Numerous research findings have established the presence of other classes of phytoconstituents in all parts of plant, which are detected by qualitative phyto- 
chemical screening. These include alkaloids, phenolics, saponins, flavonoids, triterpenoids, glycosides, tannins and amino acids. However, more detailed studies should be carried out in order to further isolate and explore the new bioactive metabolites from E. laevis, which could become a potential therapeutic candidate for the treatment of diverse disorders.

\section{Pharmacological Reports}

A wide variety of phytoconstituents are present in E. laevis, many of which exhibited an array of pharmacological activities. Several ethnobotanical survey studies reported the characteristic uses of the plant in the treatment of ailments, including jaundice and liver diseases, chronic and acute inflammations, ulcers and gums problems, wound healing and pains $[15,16,18-21]$. This part of the review will emphasize on its pharmacological studies reported for E. laevis extracts, fractions and of its phytoconstituents, along with their ethnopharmacological relevance.

\subsection{Anti-inflammatory, Antiarthritic and Analgesic Activities}

An ethnobotanical survey revealed that the tribes of rural and forest remote areas are still depending to a great extent on indigenous system of medicine $[5,75,127]$. The community of Jalpaiguri district, West Bengal local people apply the paste from the bark of E. laevis to treat painful limbs [19]. The bark juice of the plant can also be used traditionally in obstetric practice for the relief of delivery pain [18]. The plant has been recommended as an ethnic remedy for pain and inflammation. In the community of Amravati District, Maharashtra, the people also apply the root extract for the cure of inflammation [15]. Recently, in vivo studies established the anti-inflammatory potential of methanol, chloroform and aqueous extracts of E. laevis [31,191], including its potential for the treatment of arthritis, a condition characterized by chronic inflammation [192]. Besides, the methanolic extract of E. laevis leaves has been investigated for its antiarthritic activity in induced arthritis models in rats [193-195]. Phytoconstituents like hexadecanoic acid (palmitic acid), oleanolic acid, and other fixed oils were suggested to be responsible for its antiarthritic actions. Although systematic scientific studies are still lacking, forthcoming work will probably produce interesting consequences and may provide a prospective remedial candidate from E. laevis for the treatment of inflammatory disorders $[196,197]$.

\subsection{Antioxidant Activity}

Several studies suggest the antioxidant potential of plant E. laevis. Antioxidants are the substances which have capacity to inhibit or delay the oxidation process under the influence of either reactive oxygen species or environmental oxygen [198]. Antioxidants are compounds which protect living organisms from damage caused by concomitant lipid peroxidation, protein damage; uncontrolled ROS production and breaking of the deoxyribonucleic acid (DNA) strand [199]. In Ayurveda, there are many plants that possess antioxidant potential and can be used against diseases in which free radicals and ROS play an important role [200]. Ethnomedical literature reports reveal that the plant. E. laevis contains compounds like ascorbic acid, phenolic acids, flavonoids, carotenoids and polyphenolic acids, which have the tendency to scavenge free radicals such as hydroperoxide, lipid peroxyl or peroxide and thus hamper oxidative stress that causes degenerative diseases [201].

Various in vitro studies account for antioxidant potential of the plant E. laevis. The antioxidant effect of bark extracts of E. laevis was investigated using 2,2-diphenyl-1picrylhydrazyl (DPPH) radical scavenging, hydrogen peroxide, nitric oxide radical scavenging and reducing capacity assay. The methanolic and hydroalcoholic extracts scavenged DPPH radical $(87.13 \%$ and $72.35 \%)$, nitric acid $(85.08 \%$ and $74.74 \%)$ and hydrogen peroxide $(87.55 \%, 76.39 \%)$ at $200 \mu \mathrm{g} / \mathrm{mL}$. The flavonoids and phenolic contents were determined using aluminium chloride colorimetric assay and Folin-Ciocalteu's method respectively. Investigators quantified total flavonoids and phenolic contents from methanolic extract were found to be $78.75 \mathrm{mg} / \mathrm{g}$ in terms of the quercetin equivalent and $89.55 \mathrm{mg} / \mathrm{g}$ in terms 
of the gallic acid equivalent respectively [9,202]. A study of the antioxidant activity of leaf extract of E. laevis showed that it exhibited significant antioxidant activity with a minimal inhibitory concentration (MIC) value of $0.02 \mathrm{mg} / \mathrm{mL}$ [203]. Another study investigated the antioxidant capability of the leaves and stems of E. laevis, in which the ethanolic extracts of the leaves and stem were subjected to DPPH scavenging activity [204]. This revealed that the antioxidant ability of ethanolic extract of leaves and stem, measured by DPPH radical scavenging power, showed $\mathrm{IC}_{50}$ values 2.44 and $29.88 \mu \mathrm{g} / \mathrm{mL}$, respectively. The total flavonoid and phenolic contents of ethanolic extracts of leaves and stem E. laevis were calculated to be 18.19 and $1.29 \mathrm{mg} / \mathrm{g}$ in terms of quercetin equivalent and $19.02 \mathrm{mg} / \mathrm{g}$ and $7.84 \mathrm{mg} / \mathrm{g}$ in terms of catechol equivalent, respectively [204].

In another study, the methanolic extract of E. laevis fruits was reported for antioxidant effects [37]. The plant displayed its antioxidant effects due to the presence of phytomolecules such as flavonoids, tannins, ascorbic acid and phenolic acids. In vitro antioxidant activity of methanolic extract of fruits have been established using DPPH, hydrogen peroxide, hydroxyl radical and nitric oxide scavenging assays, along with ferrous chelating assays. The methanolic extracts showed DPPH, hydrogen peroxide, hydroxyl and nitric oxide radical scavenging activities, with $\mathrm{IC}_{50}$ values of $122.56 \mu \mathrm{g} / \mathrm{mL}, 112.02 \mu \mathrm{g} / \mathrm{mL}, 14.86$ $\mu \mathrm{g} / \mathrm{mL}$ and $21.09 \mu \mathrm{g} / \mathrm{mL}$, respectively [37]. The utilization of plants containing antioxidants has been recommended in the management of several diseases in view of the fact that oxidative stress is an outcome of free radical production which occurs through cellular respiration in body has been engaged in the pathogenesis of various human diseases, including ischemia, parkinson's disease, schizophrenia, cancer, diabetes, huntington's disease, inflammation, epilepsy, arthritis, anxiety, gastritis, atherosclerosis, senile dementia, depression and asthma [205-208]. The antioxidant potential of various other parts of $E$. laevis needs to be explored further in ameliorating the oxidative stress associated disorders.

\subsection{Antimicrobial Activity}

E. laevis has been employed as an ethnic medicine for the treatment of several infectious diseases, including those of viral, fungal, protozoal and bacterial origin. Several investigations have been performed in the recent past years to authenticate the antimicrobial potential of E. laevis. For example, the plant has been tested against different Gram-positive and Gram-negative bacterial strains. The methanol, chloroform, and aqueous extracts showed inhibition of Staphylococcus aureus, Pseudomonas aeruginosa, Bacillus subtilis and Escherichia coli strains using the agar well diffusion assay [209-211]. The results reveal that all the extracts have significant antibacterial action against Gram-negative and Gram-positive bacteria, establishing that the plant has a broad spectrum of activities. Antibacterial activities of the methanol, chloroform, and aqueous extracts at different concentrations $(250,500$ and $1000 \mu \mathrm{g} / \mathrm{mL})$ inhibited the growth of all bacterial strains. The methanolic extract showed noteworthy antibacterial action against $B$. subtilis and $P$. aeruginosa [31,75].

Another study confirmed the antimicrobial action of methanolic extract of E. laevis against salivary microflora using agar well diffusion method at 400 and $800 \mu \mathrm{g} / \mathrm{mL}$ [212]. The methanolic extract inhibits the tested microorganisms with 4.8 and $6.7 \mathrm{~mm}$ of zone of inhibition respectively after $24 \mathrm{~h}$ [213]. Recently, the antimicrobial activity of isopropanol and acetone extracts of E. laevis leaves have been evaluated against Pseudomonas aeruginosa, Escherichia coli and Staphylococcus aureus. The results established that the extract was considerably effective towards S. aureus and E. coli. The antimicrobial potential was found in terms of minimum inhibitory concentration (MIC) using agar broth dilution assay. The MIC of isopropanol extract was $1 \mathrm{~mL}$ and $2.5 \mathrm{~mL}$, and for acetone extract was $1.25 \mathrm{~mL}$ and $2.5 \mathrm{~mL}$ against $E$. coli and $S$. aureus, respectively. All these findings confirm the traditionally claimed antimicrobial potential of E. laevis. There is always a tremendous demand for antimicrobial agents due to the speedy development of microbial resistance. The bioactive constituents of this plant could be excellent lead compounds in the search of new potential antimicrobial agents $[13,214,215]$. 


\subsection{Wound Healing Activity}

A tribe of Wardha district of Maharashtra, India used E. laevis for the management of wound healing and found interesting results [216]. Similarly, folklore practitioners of Garasia community of district Sirohi, Rajasthan also recommended the paste prepared from leaves of plant for early healing of cuts [18]. Thakre et al. reported the wound healing activity of paste made from leaves of E. laevis [217]. Investigators used paste in thirtyfour patients and scrutinized the patients based on several parameters such as different age groups, gender, fresh, chronic, infected and non-infected. According to Bates-Jansen wound assessment, a specified quantity of paste has been applied after an interval of seven days [217]. The results revealed that wounds were healed completely from minimum of seven days to maximum sixty-six days in all the patients except one [217].

Recently, a case report had been published on the local application of E. laevis (Khanduchakka Ghrit) in the treatment of anal fissure (Parikartika) [218,219]. It has been observed that after all the mandatory measures, the efficacy of the plant has been evaluated on the basis of clinical parameters such as bleeding, itching, pain and healing. Patients were found to be healed with no signs of bleeding, pain and itching after twenty days of local application on rectum fissure. The procedure of application was followed twice a day for the duration of one month. The assessments were carried out at 0, 7, 14 and 21 days. The follow up was also conducted after 30 and 45 days. Even during follow up assessment no signs of recurrence were reported [220]. A broad antimicrobial spectrum of barks and leaves can be a probable rationale for its wound healing property. Till now, no investigational work is presented on the wound healing activity as well as in the management of anal fissures. So, there could be a wide scope for future research to figure out the possible mechanism and possible phytoactive metabolites for wound healing effects.

\subsection{Dental Caries}

Dental caries is a foremost health trouble of oral cavity. Dental caries is initiated by the interaction of microbes on the tooth enamel [221]. It is anticipated that about 2.3 billion inhabitants suffer from dental caries globally. According to the World Health Organization (WHO) the incidences of dental caries are constantly increasing. It affects all races, genders and age groups. The prevalence of caries is about $49 \%$ before the age of 12 years, while it progressively increases from 15 years $(60 \%)$ and peaks at the age group of 60-74 (84\%) [222,223]. Salivary microflora is mainly accountable for dental caries. This salivary microflora contains cariogenic microorganisms which are involved in the process of caries formation and also perturb the normal microflora of oral cavity [224]. An ethnomedicinal survey carried out by Patil and Patil, found that the tribe of Dhule district of Maharashtra used the stem of E. laevis as a brush for the cure of ulcers of mouth and gum problems [16]. Similarly, another study reported that people living in remote areas of Rajasthan chewed the leaves of E. laevis to treat blisters of mouth [24]. The remote areas of Pakistan also use this plant for the cure of dental caries [225]. It has also been documented that several parts of the plant were used for oral fitness [226]. Young branches of E. laevis were also employed for the relief of toothache [35]. Recently, Deshpande et al. investigated that the methanolic and ethanolic extracts of E. laevis inhibited the zone of inhibition towards salivary microflora at different concentrations (50, 100, 200, 400 and $800 \mu \mathrm{g} / \mathrm{mL}$ ). It has been found that the methanolic extract at $100 \mu \mathrm{g} / \mathrm{mL}$ showed feeble antimicrobial action, whereas the zone of inhibition was increased up to $8.4 \mathrm{~mm}$ at 800 $\mu \mathrm{g} / \mathrm{mL}$ [227]. All these documented reports validate the traditional uses of $E$. laevis towards microbial diseases of oral tissues. A wide antimicrobial spectrum of E. laevis can be very helpful in the prevention of dental problems. Therefore, all these studies confirmed that $E$. laevis has the potential for the therapeutic management of oral/dental problems.

\subsection{Miscellaneous Activities}

E. laevis had also been studied for its coagulant and edible properties. Moreover, several other parts of the plant were recommended for the treatment of jaundice, skin 
diseases and in bone fractures. In another ethnobotanical survey the folklore practitioner of Uttarakhand recommended the paste prepared from the seeds of E. laevis mixed with cardamom powder and to be administered with milk three times a day for the management of jaundice and in other liver problems [20]. Recently, the coagulant potential of extracts of E. laevis leaves has been evaluated, revealing that the coagulant potential of isopropanol extract is more significant than the acetone extract [228].

E. laevis has also been used by tribal people and recommended by folklore hakeem for the management and healing of fractures. Tichkule et al. reported the use of paste prepared from the leaves of E. laevis for the management of fracture. The kalka (paste) was applied in the form of lepan (applied locally) at the affected sites [14,229]. The dressing is applied daily then covered by rubber pads and support has been provided using slabs of plaster of paris. A bandage was applied over the whole part of the foot and leg. After the application of lepan for 10 days, it was found that the swelling and pain had been abridged gradually and patients became able to move without any kind of support. The assessment of swelling was done using the American Orthopedic Foot and Ankle Scale (AOFAS) [230]. The X-ray reports of patients revealed that the application of lepan of the plant over the fractured portion for two weeks lead to callus formation and unite malunion of metatarsal. Sharma, et al. established that the Tharu community of Uttrakhand used the ground paste of leaves of E. laevis has been applied topically for the treatment of diverse skin disorders $[18,21,33]$. In another study, the antidiabetic perspective of E. laevis has been established through electrochemical measurement using multi-walled nano carbon tubes [76,231].

\section{Toxicology}

The therapeutic perspective of the plant or isolated molecule is considered commendable when it is devoid of any sign of adverse effects or toxicity. It is well acknowledged that toxicity studies are of most imperative for natural products and also for their isolated compounds. Even though numerous pharmacological activities of E. laevis have been established to support its pervasive traditional and customary use of the plant as antioxidant, analgesic, anti-inflammatory, antimicrobial, antiarthritic, and also used in several liver, skin, inflammatory, dysentery, infectious, and dental problems. None of the research groups approved any toxicity of the plant. Moreover, the plant is widely accepted as food, as its ripened fruits are eaten by tribal people. Only one report on acute oral toxicity study has been performed as per the organization for economic cooperation and development (OECD) guidelines 423. All the methanolic extracts of leaves, stems and fruits were considered safe at the dose of $2000 \mathrm{mg} / \mathrm{kg}$ [8]. Assessment of body weight and behavioral changes were also observed. There was no sign of toxicity (mortality), as all these three extracts showed no neurotoxic effects and were found to be safe [232,233].

The toxicity reports on E. laevis are very limited and inadequate to support the efficacy and safety of its extracts/fractions in different ailments, which may lead to delay its use as a therapeutic candidate. Likewise, with available literature reports are deficient in the scientific knowledge and toxicity of active constituents of plants. The interaction of extracts with pharmaceutical additives/drugs needs to be studied at a methodological level. It is also important to mention here that detailed pharmacodynamic and pharmacokinetic studies of the plant (E. laevis) extracts have not been investigated yet in clinical trials to transform it into its remedial use.

\section{Discussion}

E. laevis is one of the famous plants used by various tribes of tropical Asia, Africa and Australia in ethnomedical treatment of jaundice, diarrhea, cough, syphilis, dysentery, asthma, fissure, dental, skin, infectious and liver diseases [8]. Pharmacological investigations carried out on various plant parts, crude extracts/fractions and isolated molecules of E. laevis grant a realistic support for its conventional uses. Recent studies have been paying attention to the investigation of antioxidant, analgesic, anti-inflammatory, antiarthritic, antimicrobial, wound healing activities. Most of the performed pharmacological activi- 
ties were intended to authenticate its customary uses. Several traditional uses have been explored by various investigators. Its therapeutic use for dental problems, treatment of fissure, skin diseases, diarrhea, dysentery, cuts and wound healing were supported by its antimicrobial potential. E. laevis has been used historically in inflammation, arthritis and liver problems. These traditional claims have been supported by its in vitro antioxidant activities. All these pharmacological activities have been evaluated by using various assays. Its pentacyclic triterpenoids, flavonoids and phenolic compounds may be responsible for the above-mentioned activities. Further investigations are still required to be carried out to identify the possible mechanism and to pinpoint the bioactive phytoconstituents of $E$. laevis responsible for mitigation of various diseases.

Quantitative analyses have been carried out by the researchers led to the investigation of a few classes of bioactive phytochemicals. However, pentacyclic triterpenoids and phenolic compounds got attention by several researchers [7,9]. No research group had isolated active constituents such as alkaloids and saponins. Despite numerous research groups signify the presence of these classes of phytoconstituents in all parts of plant by qualitative phytochemical screening [6-9,85]. Further detailed phytochemical studies need to be carried out to isolate and to explore the new bioactive metabolites from E. laevis so that these may emerge as potential therapeutic candidates for the treatment of diverse disorders. Additionally, till today clinical and preclinical studies have not been performed in detail to support its efficacy and safety in rodents as well as in humans. This review article is very helpful for the scientific community as it provides insights for reviewers, readers, researchers and academicians who are working in the area of phytochemistry to understand E. laevis perspectives for in depth investigations.

Nevertheless, the enormous customary uses and proven pharmacological activities of E. laevis reveal that a wide scope still subsists for its phytochemical investigation. Several studies described sound pharmacological activities of E. laevis, which could be investigated further for maximum utilization of this plant as a remedy for various ailments. The plant contains flavonoids and amino acids like tryptophan, asparagine, glutamic acid, histidine etc. The use of plant-based amino acids have been recommended to alleviate in tumor, liver and neuropsychiatric complications. Hence, this plant can also be explored for cancer, liver and central nervous system (CNS) disorders [20,34,80,233].

The present review compiles published information on the isolated phytoconstituents, reported activities and toxicity of E. laevis. Authors have tried to summarize relevant data on phytochemistry including the structures of isolated molecules from different extracts, pharmacological evaluation, folklore uses and common names of the plant in different languages (see Supplementary Materials, Table S1). This work highlighted up to date records and gaps in research, which exists for this plant to categorize it as a prospective ethnopharmacological and potential therapeutic plant.

\section{Conclusions}

This review presents the ethnobotanical description, ethnopharmacological uses, bioactive phytometabolites and pharmacological properties of E. laevis. This plant exhibited fascinating therapeutic perspectives. However, all the reported pharmacological studies were limited and scientifically incapable to validate it as a potential candidate for the cure of ethnomedical disorders. Up till now, no clinical or detailed preclinical investigations had been carried out to endorse its safety. Sporadic phytochemical work was carried out to isolate its active phytoconstituents, following the bioactivity-guided fractionation approach. The available literature also reveals that no work has been performed towards standardization of plants. Though the plant possesses significant scientific and traditional data to justify its medicinal value, modern approaches like molecular docking, quantitative structure-activity relationship studies and development of leads from E. laevis are completely missing. The article presents the gigantic gaps in research investigations done on $E$. laevis. In addition, detailed preclinical and clinical trials ought to be explored in future to evaluate E. laevis clinical effectiveness and safety in humans. The results of the upcoming 
investigations on the above-mentioned areas will certainly offer persuasive support for the future clinical significance of E. laevis in modern medicine.

Supplementary Materials: The following are available online, Table S1: Common names of E. laevis. $[2,16,21,23,28,227,234,235]$.

Author Contributions: Conceptualization, F.N.-K. and S.K.; methodology, R.S. and P.S. software, data curation, P.S.; writing-original draft preparation, P.S., R.S. and S.K., writing-review and editing, F.N.-K. and S.K.; visualization, R.S.; and S.K.; supervision, F.N.-K., S.K. and P.S.; project administration, F.N.-K. and P.S.; funding acquisition, F.N.-K. All authors have read and agreed to the published version of the manuscript.

Funding: F.N.-K. would also like to acknowledge an equipment subsidy and return fellowship from the Alexander von Humboldt Foundation, Germany and financial support from the German Academic Exchange services (DAAD) through the guest professorship program.

Institutional Review Board Statement: Not applicable.

Informed Consent Statement: Not applicable.

Data Availability Statement: No new data were created or analyzed in this study. Data sharing is not applicable to this article.

Acknowledgments: Authors are thankful to Vice-Chancellor of Punjabi University Patiala, India for his encouragement. The authors are also thankful to Er. S. K. Punj, Chairman, Sri Sai Group of Institutes and Smt. Tripta Punj, Managing Director, Sri Sai Group of Institutes for their constant moral support.

Conflicts of Interest: The authors declare no conflict of interest.

\section{References}

1. Miller, J.S. A revision of the new world species of Ehretia (Boraginaceae). Ann. Mo. Bot. Gard. 1989, 76, 1050-1076. [CrossRef]

2. Joshi, S.G. Medicinal Plants; Oxford and IBH Publishing Co. Private Ltd.: New Delhi, India, 2000; p. 102.

3. Khare, C.P. Indian Medicinal Plants; An Illustrated Dictionary; Society for New Age Herbals: New Delhi, India, 2007 ; pp. $231-232$.

4. Kirtikar, K.R.; Basu, B.D. Indian Medicinal Plants; Lalit Mohan Publication: Allahabad, India, 1935; Volume 3, pp. $1680-1681$.

5. Sastri, B.N. The Wealth of India; A Dictionary of Indian Raw Materials and Industrial Products; Council of Scientific and Industrial Research: New Delhi, India, 1952; Volume 3, p. 129.

6. Torane, R.C.; Ruikar, A.D.; Chandrachood, P.S.; Deshpande, N.R. Study of amino acids and carbohydrates from the leaves of Ehretia Laevis. Asian J. Chem. 2009, 21, 1636-1638.

7. Li, L.; Yong, P.; Xia, Y.; Li-Jia, X.; Ta-Na, W.; Yong, L.; Ren-Bing, S.; Pei-Gen, X. Chemical constituents and biological activities of plants from the genus Ehretia Linn. Chin. Herb. Med. 2010, 2, 106-111.

8. Velappan, S.; Thangaraj, P. Phytochemical constituents and antiarthritic activity of Ehretia laevis Roxb. J. Food Biochem. 2014, 38, 433-443. [CrossRef]

9. Joshi, U.P.; Wagh, R.D. GC-MS analysis of phytochemical compounds present in the bark extracts of Ehretia laevis Roxb. Int. J. Res. Dev. Pharm. Life Sci. 2018, 7, 3150-3154. [CrossRef]

10. Rangnathrao, T.S.; Shanmugasundar, P. Preliminary phytochemical screening and HPTLC method for qualitative determination of phytochemical compounds in extract of Ehretia laevis Roxb. J. Pharmacogn. Phytochem. 2018, 7, 867-874.

11. Admuthe, N.B.; Nalwade, A.R. Micropropagation for Ehretia laevis Roxb.: A rare Indian medicinal plant. Int. J. Adv. Sci. Res. 2016, $3,411-422$.

12. Khobragade, P.; Khobragade, M.; Nandgaonkar, P. Pharmacognostic and phytochemical studies on the leaves of Khanduchakka (Ehretia laevis Roxb.): A folklore plant. J. Indian Med. Sys. 2017, 5, 71-74.

13. Thakre, R.; Bhutada, S.; Chouragade, B.; Khobragde, P.; Harne, K. Ethnobotanical properties of unexplored plant Khandu chakka (Ehretia laevis Roxb.). Int. J. Ayurveda Pharma. Res. 2016, 4, 68-73.

14. Anonymous. The Ayurvedic Formulary of India; Ministry of Health and Family Welfare, Government of India: New Delhi, India, 1978; pp. 1-120.

15. Padhye, M.D.; Deshmukh, V.K.; Tiwari, V.J. Ethnobotanical study of the Korku tribe of Amravati district, Maharashtra state, India. Int. J. Pharmacogn. 1992, 30, 17-20. [CrossRef]

16. Patil, S.L.; Patil, D.A. Ethnomedicinal plants of Dhule district of Maharashtra. Nat. Prod. Radiance 2007, 6, 148-151.

17. Dhenge, S.; Khandare, K. Efficacy of local application of Khandu chakka (Ehretia laevis roxb) Ghrita in Dushtavrana-A case report. Int. J. Ayurveda Integr. Med. 2016, 7, 3726-3731.

18. Meena, K.L.; Yadav, B.L. Some ethnomedicinal plants used by the Garasia tribe of Siroh, Rajasthan. Indian J. Trad. Knowl. 2011, 10, 354-357. 
19. Bose, D.; Roy, J.G.; Mahapatra, S.D.; Datta, T.; Mahapatra, S.D.; Biswas, H. Medicinal plants used by tribals in Jalpaiguri district, West Bengal, India. J. Med. Plants Stud. 2015, 3, 15-21.

20. Sharma, J.; Gairola, S.; Gaur, R.D.; Painuli, R.M. The treatment of jaundice with medicinal plants in indigenous communities of the Sub-Himalayan region of Uttarakhand, India. J. Ethnopharmacol. 2012, 143, 262-291. [CrossRef] [PubMed]

21. Sharma, J.; Gairola, S.; Sharma, Y.P.; Gaur, R.D. Ethnomedicinal plants used to treat skin diseases by Tharu community of district Udham Singh Nagar, Uttarakhand, India. J. Ethnopharmacol. 2014, 158, 140-206. [CrossRef]

22. Liu, R.H. Health benefits of fruits and vegetables are from additive and synergistic combinations of phytochemicals. Am. J. Clin. Nutr. 2003, 78, 517-520. [CrossRef] [PubMed]

23. Torane, R.C.; Kamble, G.S.; Gadkari, T.V.; Tambe, A.S.; Deshpande, N.R. GC-MS study of nutritious leaves of Ehretia laevis. Int. J. Chem. Res. 2011, 3, 1589-1591.

24. Jain, A.; Katewa, S.S.; Galav, P.; Nag, A. Some therapeutic uses of biodiversity among the tribes of Rajasthan. Indian J. Tradit. Knowl. 2008, 7, 256-262.

25. Mishra, N.; Pareek, A. Floristic diversity of angiosperms with special reference to their medicinal properties from Kota district of Rajasthan, India. Int. J. Adv. Res. 2015, 3, 994-1007.

26. Deshpande, R.; Kamath, A.; Chaturvedi, S.; Mutha, M.M.; Shep, S.; Torane, R. Comparative evaluation of antimicrobial properties of different extracts of 'Ehretia laevis' against salivary microflora. Res. J. Pharm. Biol. Chem. Sci. 2014, 5, 489-491.

27. Tripathi, S.; Ray, S.; Mondal, A.K.; Verma, N.K. Rare ethno medicinal plants of South West Bengal, India with their different medicinal uses: Needs conversation. Int. J. Life Sci. Biotechnol. Pharma Res. 2013, 2, 114-122.

28. Soni, V.; Prakash, A.; Nema, M. Study on ethno medicinal botany of some plants of Dindori district of Madhya Pradesh, India. Int. J. Pharm. Pharm. Sci. 2012, 8, 1926-1929.

29. Mohammad, S.; Ghiasi, J.; Chen, A. Bone fracture healing in mechanobiological modelling: A review of principles and methods. Bone Rep. 2017, 6, 87-100.

30. Das, P.K.; Mondal, A.K. Report to the rare and endangered medicinal plant resources in the dry deciduous forest areas of Paschim Medinipur district, West Bengal. Int. J. Drug Dis. Herbal Res. 2012, 2, 418-429.

31. Jyothirmai, N.; Nagaraju, B.; Deepika, M.Y.; Kumar, J.N.; Rani, G.S. Evaluation of anti-inflammatory and antibacterial activities of different solvent extracts of Ehretia laevis Roxb. Int. J. Pharm. Sci. Res. 2016, 8, 715-720.

32. Ali, S.J.; Nasir, Y.J. Flora of Pakistan; National Herbarium, NARC, Department of Botany, University of Karachi: Islamabad, Karachi, Pakistan, 1989; pp. 191-193.

33. Gaur, R.D.; Sharma, J. Indigenous knowledge on the utilization of medicinal plant diversity in Siwalik region of Garhwal Himalaya, Uttarakhand. J. For. Sci. 2011, 27, 23-31.

34. Torane, R.C.; Kamble, G.S.; Chandrachood, P.S.; Deshpande, N.R. Preliminary phytochemical screening and nutritional analysis of leaves of Ehretia laevis. J. Pharm. Res. 2010, 3, 1384-1385.

35. Jagtap, S.D.; Deokule, S.; Pawar, P.K.; Harsulkar, A.M. Traditional ethno medicinal knowledge confined to the Pawra tribe of Satpura Hills, Maharashtra, India. Ethnobot. Leaflets 2009, 13, 98-115.

36. Chander, M.P.; Kartick, C.; Vijayachari, P. Herbal medicine and healthcare practices among Nicobarese of Nancowry group of Islands, an indigenous tribe of Andaman \& Nicobar Islands. Indian J. Med. Res. 2015, 141, 720-744.

37. Sivasankari, V.; Revathi, P.; Parimela, Z. Evaluation of in vitro antioxidant activity in edible fruits of Ehretia laevis Roxb. Int. J. Pharma Bio Sci. 2013, 4, 847-857.

38. Dan, S.; Dan, S.S. Triterpenoids of the bark of Ehretia laevis. Fitoterapia 1982, 53, 51-52.

39. Thapliyal, P.C.; Yadav, S.K. A new naphthoquinone from aerial parts of Ehretia laevis. J. Inst. Chem. 2003, 75, 13-15.

40. Ali, M. Textbook of Pharmacognosy, 2nd ed.; CBS Publishers: Daryaganj, New Delhi, India, 2007; pp. 490-504.

41. Torane, R.C.; Kamble, G.S.; Kale, A.A.; Gadkari, T.V.; Deshpande, N.R. Quantification of dioctyl phthalate from Ehretia laevis Roxb by HPTLC. J. Chem. Pharm. Res. 2011, 3, 48-51.

42. Bringmann, G.; Saeb, W.; Assi, L.A.; Francois, G.; Narayanan, A.S.S.; Peters, K.; Peters, E.M. Betulinic acid: Isolation from Triphyophyllum peltatum and Ancistrocladus heyneanus, antimalarial activity, and crystal structure of the benzyl ester. Planta Med. 1997, 63, 255-257. [CrossRef]

43. Huguet, A.I.; Recio, M.D.C.; Manez, S.; Giner, R.M.; Rios, J.L. Effect of triterpenoids on the inflammation induced by protein kinase C activators, neuronally acting irritants and other agents. Eur. J. Pharmacol. 2000, 410, 69-81. [CrossRef]

44. Kinoshita, K.; Akiba, M.; Saitoh, M.; Ye, Y.; Koyama, K.; Takahashi, K.; Kondo, N.; Yuasa, H. Antinociceptive effect of triterpenes from Cacti. Pharm. Biol. 1998, 36, 50-57. [CrossRef]

45. Chandramu, C.; Manohar, R.D.; Krupadanam, D.G.; Dashavantha, R.V. Isolation, characterization and biological activity of betulinic acid and ursolic acid from Vitex negundo L. Phytother. Res. 2003, 17, 129-134. [CrossRef] [PubMed]

46. Fulda, S.; Debatin, K.M. Betulinic acid induces apoptosis through a direct effect on mitochondria in neuroectodermal tumors Med. Pediatr. Oncol. 2000, 35, 616-618. [CrossRef]

47. Zuco, V.; Supino, R.; Righetti, S.C.; Cleris, L.; Marchesi, E.; Gambacorti-Passerini, C.; Formelli, F. Selective cytotoxicity of betulinic acid on tumor cell lines, but not on normal cells. Cancer Lett. 2002, 175, 17-25. [CrossRef]

48. Zhao, J.; Li, R.; Pawlak, A.; Henklewska, M.; Sysak, A.; Wen, L.; Yi, J.; Obminska-Mrukowicz, B. Antitumor activity of betulinic acid and betulin in canine cancer cell lines. In Vivo 2018, 32, 1081-1088. [CrossRef]

49. Krasutsky, P.A. Birch bark research and development. Nat. Prod. Rep. 2006, 23, 919-942. [CrossRef] [PubMed] 
50. Krol, S.K.; Kielbus, M.; Rivero-Müller, A.; Stepulak, A. Comprehensive review on betulin as a potent anticancer agent. Natural bioactive in cancer treatment and prevention. BioMed Res. Int. 2015, 2015, 584189. [CrossRef] [PubMed]

51. Pavlova, N.I.; Savinova, O.V.; Nikolaeva, S.N.; Boreko, E.I.; Flekhter, O.B. Antiviral activity of betulin, betulinic and betulonic acids against some enveloped and non-enveloped viruses. Fitoterapia 2003, 74, 489-492. [CrossRef]

52. Bernard, P.; Scior, T.; Didier, B.; Hibert, M.; Berthon, J. Ethnopharmacology and bioinformatic combination for lead discovery: Application to phospholipase A2 inhibitors. Phytochemistry 2001, 58, 865-874. [CrossRef]

53. Simone, F. Betulinic acid for cancer treatment and prevention. Int. J. Mol. Sci. 2008, 9, 1096-1107.

54. Dzubak, P.; Hajduch, M.; Vydra, D.; Hustova, A.; Kvasnica, M.; Biedermann, D.; Ova, L.M.; Urban, M.; Sarek, J. Pharmacological activities of natural triterpenoids and their therapeutic implications. Nat. Prod. Res. 2006, 23, 394-411.

55. Geetha, T.; Varalakshmi, P. Anti-inflammatory activity of lupeol and lupeol linoleate in rats. J. Ethnopharmacol. 2001, 76, 77-80. [CrossRef]

56. Tsai, F.S.; Lin, L.W.; Wu, C.R. Lupeol and its role in chronic diseases. Adv. Exp. Med. Biol. 2016, 929, 145-175.

57. Fernandez, M.A.; de las Heras, B.; Garcia, M.D.; Saenz, M.T.; Villar, A. New insights into the mechanism of action of the anti-inflammatory triterpene lupeol. J. Pharm. Pharmacol. 2001, 53, 1533-1539. [CrossRef]

58. Sudhahar, V.; Kumar, S.A.; Sudharsanm, P.T.; Varalakshmi, P. Protective effect of Lupeol and its ester on cardiac abnormalities in experimental hypercholesterolemia. Vascul. Pharmacol. 2007, 46, 412-418. [CrossRef]

59. Alam, P.; Al-Yousef, H.M.; Siddiqui, N.A.; Alhowiriny, T.A.; Alqasoumi, S.I.; Amina, M.; Hassan, W.H.B.; Abdelaziz, S.; Abdalla, R.H. Anticancer activity and concurrent analysis of ursolic acid, $\beta$-sitosterol and lupeol in three different species of Hibiscus species by validated HPTLC method. Saudi Pharm. J. 2018, 26, 1060-1067. [CrossRef]

60. Bag, P.; Chattopadhyay, D.; Mukherjee, H.; Ojha, D.; Mandal, N.; Sarkar, M.C.; Chatterjee, T.; Das, G.; Chakraborti, S. Anti-herpes virus activities of bioactive fraction and isolated pure constituents of Mallotus peltatus an ethnomedicine from Andaman Islands. Virol. J. 2012, 9, 98-109. [CrossRef]

61. Gupta, M.B.; Nath, R.; Gupta, G.P.; Bhargava, K.P. Antiulcer activity of some plant triterpenoids. Indian J. Med. Res. 1981, 73, 649-652. [PubMed]

62. Hirota, M.; Mori, T.; Yoshida, M.; Iriye, R. Antitumor-promoting and anti-inflammatory activities of triterpenoids and sterols from plants and fungi. Agric. Biol. Chem. 1990, 54, 1073-1075.

63. Aragao, G.F.; Carneiro, L.M.V.; Junior, A.P.F.; Vieira, L.C.; Bandeira, P.N.; Lemos, T.L.G.; Viana, G.S. A possible mechanism for anxiolytic and antidepressant effects of alpha- and beta-amyrin from Protium heptaphyllum (Aubl.). Pharmacol. Biochem. Behav. 2006, 85, 827-834. [CrossRef] [PubMed]

64. Johann, S.; Soldi, C.; Lyon, J.P.; Pizzolath, M.G.; Resende, M.A. Antifungal activity of the amyrin derivatives and in vitro inhibition of Candida albicans adhesion to human epithelial cells. Lett. Appl. Microbiol. 2007, 45, 148-153. [CrossRef]

65. Okoye, N.N.; Ajaghaku, D.L.; Okeke, H.N.; Ilodigwe, E.E.; Nworu, C.S.; Okoye, F.B.C. $\beta$-amyrin and $\alpha$-amyrin acetate isolated from the stem bark of Alstonia boonei display profound anti-inflammatory activity. Pharm. Biol. 2014, 52, 1478-1486. [CrossRef] [PubMed]

66. Santos, F.A.; Frota, J.T.; Arruda, B.R.; de Melo, T.S.; da Silva, A.A.; de Castro Brito, G.A.; Chaves, M.H.; Rao, V.S. Antihyperglycemic and hypolipidemic effects of $\alpha, \beta$-amyrin, a triterpenoid mixture from Protium heptaphyllum in mice. Lipids Health Dis. 2012, 11, 98-106. [CrossRef] [PubMed]

67. Kathryn, A.B.; da Silva, S.; Paszcuk, A.F.; Passos, G.F.; Silva, S.E.; Bento, A.F.; Meotti, F.C.; Calixto, J.B. Activation of cannabinoid receptors by the pentacyclic triterpene $\alpha, \beta$-amyrin inhibits inflammatory and neuropathic persistent pain in mice. Pain 2011, 152, 1872-1887.

68. Melo, C.M.; Carvalho, K.M.M.B.; Neves, J.C.S.; Morais, T.C.; Rao, V.S.; Santos, F.A.; Brito, G.A.B.; Chaves, M.H. $\alpha, \beta$-amyrin, a natural triterpenoid ameliorates L-arginine induced acute pancreatitis in rats. World J. Gastroenterol. 2010, 16, 4272-4280. [CrossRef] [PubMed]

69. Batovska, D.I.; Todorova, I.T.; Nedelcheva, D.V.; Parushev, S.P.; Atanassov, A.J.; Hvarleva, T.D.; Djakova, G.J.; Bankova, V.S. Preliminary study on biomarkers for the fungal resistance in Vitis vinifera leaves. J. Plant. Physiol. 2008, 165, 791-795. [CrossRef] [PubMed]

70. Jabeen, K.; Javaid, A.; Ahmad, E.; Athar, M. Antifungal compounds from Melia azederach leaves for management of Ascochyta rabiei, the cause of chickpea blight. Nat. Prod. Res. 2011, 25, 264-276. [CrossRef] [PubMed]

71. Vitor, C.E.; Figueiredo, C.P.; Hara, D.B.; Bento, A.F.; Mazzuco, T.L.; Calixto, J.B. Therapeutic action and underlying mechanisms of a combination of two pentacyclic triterpenes alpha- and beta-amyrin, in a mouse model of colitis. Br. J. Pharmacol. 2009, 157, 1034-1044. [CrossRef] [PubMed]

72. Awad, A.B.; Roy, R.; Fink, C.S. $\beta$-sitosterol, a plant sterol, induces apoptosis and activates key caspases in MDA-MB-231 human breast cancer cells. Oncol. Rep. 2003, 10, 497-500. [CrossRef]

73. Kumar, D.; Nepali, K.; Bedi, P.M.S.; Kumar, S.; Malik, F.; Jain, S. 4,6-diaryl Pyrimidones as Constrained Chalcone Analogues: Design, Synthesis and Evaluation as Antiproliferative Agents. Anticancer Agents Med. Chem. 2015, 15, 793-803. [CrossRef]

74. Kumar, D.; Singh, O.; Nepali, K.; Bedi, P.M.S.; Qayum, A.; Singh, S.; Jain, S.K. Naphthoflavones as anti-proliferative agents: Design, synthesis and biological evaluation. Anticancer Agents Med. Chem. 2016, 16, 881-890. [CrossRef]

75. Shukla, A.; Kaur, A. A systematic review of traditional uses bioactive phytoconstituents of genus Ehretia. Asian J. Pharm. Clin. Res. 2018, 11, 88-100. [CrossRef] 
76. Kumar, D.; Sharma, P.; Nepali, K.; Mahajan, G.; Mintoo, M.J.; Singh, A.; Singh, G.D.; Mondhe, D.M.; Singh, G.; Jain, S.K.; et al. Antitumour, acute toxicity and molecular modelling studies of 4-(pyridine-4-yl)-6-(thiophen-2- yl)pyrimidin-2(1H)-one against Ehrlich ascites Carcinoma and sarcoma-180. Heliyon 2018, 4, 61. [CrossRef]

77. Kumar, D.; Malik, F.; Bedi, P.M.S.; Jain, S. 2,4-Diarylpyrano[3,2-c]chromen-5(4H)-ones as Antiproliferative Agents: Design, Synthesis and Biological Evaluation. Chem. Pharm. Bull. 2016, 64, 399-409. [CrossRef]

78. Kumar, D.; Jain, S.K. A Comprehensive Review of N-Heterocycles as Cytotoxic Agents. Curr. Med. Chem. 2016, 23, 4338-4394. [CrossRef]

79. Sharma, P.; Sharma, R.; Rao, H.S.; Kumar, D. Phytochemistry and Medicinal Attributes of A. Scholaris: A Review. Int. J. Pharm. Sci. Res. 2015, 6, 505-513.

80. Kumar, D.; Sharma, P.; Singh, H.; Nepali, K.; Gupta, G.K.; Jain, S.K.; Ntie-Kang, F. The value of pyrans as anticancer scaffolds in medicinal chemistry. RSC Adv. 2017, 7, 36977-36999. [CrossRef]

81. Kaur, T.; Sharma, P.; Gupta, G.; Ntie-Kang, F.; Kumar, D. Treatment of Tuberculosis by Natural Drugs: A Review. Plant. Arch. 2019, 19, 2168-2176.

82. Kumar, D.; Singh, G.; Sharma, P.; Qayum, A.; Mahajan, G.; Mintoo, M.J.; Singh, S.K.; Mondhe, D.M.; Bedi, P.M.S.; Jain, S.K.; et al. 4-aryl/heteroaryl-4H-fused pyrans as Anti-proliferative Agents: Design, Synthesis and Biological Evaluation. Anticancer Agents Med. Chem. 2018, 18, 57-73. [CrossRef] [PubMed]

83. Bekono, B.D.; Ntie-Kang, F.; Onguene, P.A.; Lifongo, L.L.; Sippl, W.; Fester, K.; Owono, L.C.O. The potential of antimalarial compounds derived from African medicinal plants: A review of pharmacological evaluations from 2013 to 2019. Malar. J. 2020, 9 , $1-35$.

84. Zhishen, J.; Cheng, T.; Jianming, W. The determination of flavonoid contents on mulberry and their scavenging effects on superoxide radical. Food Chem. 1999, 64, 555-559. [CrossRef]

85. Hakkinen, S.H.; Karenlampi, S.O.; Heinonen, I.M.; Mykkanen, H.M.; Torronen, A.R. Content of the flavonols quercetin, myricetin, and kaempferol in 25 edible berries. J. Agric. Food Chem. 1999, 47, 2274-2279. [CrossRef]

86. Stewart, A.J.; Bozonnet, S.; Mullen, W.; Jenkins, G.I.; Lean, M.E.; Crozier, A. Occurrence of flavonols in tomatoes and tomato-based products. J. Agric. Food Chem. 2000, 48, 2663-2669. [CrossRef] [PubMed]

87. Ferry, D.R.; Smith, A.; Malkhandi, J. Phase I clinical trial of the flavonoid quercetin: Pharmacokinetics and evidence for in vivo tyrosine kinase inhibition. Clin. Cancer Res. 1996, 2, 659-668.

88. Davis, W.L.; Matthew, S.B. Antioxidants and cancer III: Quercetin. Altern. Med. Rev. 2000, 5, 196-208.

89. Zerin, T.; Kim, Y.S.; Hong, S.Y.; Song, H.Y. Quercetin reduces oxidative damage induced by paraquat via modulating expression of antioxidant genes in A549 cells. J. Appl. Toxicol. 2013, 33, 1460-1467. [CrossRef]

90. Lesjak, M.; Beara, I.; Simin, N.; Pintac, D.; Majkic, T.; Bekvalac, K.; Orcic, D.; Mimica-Dukic, N. Antioxidant and anti-inflammatory activities of quercetin and its derivatives. J. Funct. Foods 2018, 40, 68-75. [CrossRef]

91. Boots, A.W.; Haenen, G.; Bast, A. A health effect of quercetin: From antioxidant to nutraceutical. Eur. J. Pharmacol. 2008, 585, 325-337. [CrossRef] [PubMed]

92. Xu, D.; Hu, M.J.; Wang, Y.Q.; Cui, Y.L. Antioxidant activities of quercetin and its complexes for medicinal application. Molecules 2019, 24, 1123. [CrossRef]

93. Jain, A.K.; Thanki, K.; Jain, S. Co-encapsulation of tamoxifen and quercetin in polymeric nanoparticles: Implications on oral bioavailability, antitumor efficacy, and drug induced toxicity. Mol. Pharm. 2013, 10, 3459-3474. [CrossRef]

94. Miean, K.H.; Mohamed, S. Flavonoid (myricetin, quercetin, kaempferol, luteolin and apigenin) content of edible tropical plants. J. Agric. Food Chem. 2001, 49, 3106-3112. [CrossRef] [PubMed]

95. Somerset, S.M.; Johannot, L. Dietary flavonoid source in Australian adults. Nutr. Cancer 2008, 60, 442-449. [CrossRef] [PubMed]

96. Chen, A.Y.; Chen, Y.C. A review of dietary flavonoid, Kaempferol on human health and cancer prevention. Food Chem. 2013, 138, 2099-2107. [CrossRef]

97. Suchal, K.; Malik, S.; Khan, S.I.; Malhotra, R.K.; Goyal, S.N.; Bhatia, J.; Ojha, S.; Arya, D.S. Molecular pathways involved in the amelioration of myocardial injury in diabetic rats by kaempferol. Int. J. Mol. Sci. 2017, 18, 1001. [CrossRef] [PubMed]

98. Zhao, J.; Zhang, S.; You, S.; Liu, T.; Xu, F.; Ji, T.; Gu, Z. Hepatoprotective effects of nicotiflorin from nymphaea candida against concanavalin $\alpha$-induced and $D$-galactosamine-induced liver injury in mice. Int. J. Mol. Sci. 2017, 18, 587. [CrossRef] [PubMed]

99. Nascimento, A.M.; Maria-Ferreira, D.; Lin, F.T.D.; Kimura, A.; de Santana-Filho, A.P.; de P. Werner, M.F.; Iacomini, M.; Sassaki, G.L.; Cipriani, T.R.; de Souza, L.M. Phytochemical analysis and anti-inflammatory evaluation of compounds from an aqueous extract of Croton cajucara benth. J. Pharm. Biomed. Anal. 2017, 145, 821-830. [CrossRef] [PubMed]

100. Arif, H.; Sohail, A.; Farhan, M.; Rehman, A.A.; Ahmad, A.; Hadi, S.M. Flavonoids induced redox cycling of copper ions leads to generation of reactive oxygen species: A potential role in cancer chemoprevention. Int. J. Biol. Macromol. 2018, 106, 569-578. [CrossRef]

101. Wang, L.; Tu, Y.C.; Lian, T.W.; Hung, J.T.; Yen, J.H.; Wu, M.J. Distinctive antioxidant and anti-inflammatory effects of flavonols. J. Agric. Food Chem. 2006, 54, 9798-9804. [CrossRef]

102. Wu, Y.; Sun, J.; George, J.; Ye, H.; Cui, Z.; Li, Z. Study of neuroprotective function of Ginkgo biloba extract derived-flavonoid monomers using a three-dimensional stem cell-derived neural model. Biotechnol. Prog. 2016, 32, 735-744. [CrossRef]

103. Li, F.; Zhang, B.; Chen, G.; Fu, X. The novel contributors of antidiabetic potential in mulberry polyphenols revealed by UHPLCHR-ESI-TOF-MS/MS. Food Res. Int. 2017, 100, 873-884. [CrossRef] 
104. Calderon-Montano, J.M.; Burgos-Moron, E.; Perez-Guerrero, C.; Lopez-Lazaro, M. A review on the dietary flavonoid kaempferol. Mini Rev. Med. Chem. 2011, 11, 298. [CrossRef] [PubMed]

105. Pei, J.; Chen, A.; Zhao, L.; Cao, F.; Ding, G.; Xiao, W. One pot synthesis of hyperoside by a three-enzyme cascade using a UDP galactose regeneration system. J. Agric. Food Chem. 2017, 65, 6042-6048. [CrossRef]

106. Tang, X.L.; Liu, J.X.; Dong, W.; Li, P.; Li, L.; Hou, J.C.; Zheng, Y.Q.; Lin, C.R.; Ren, J.G. Protective effect of kaempferol on LPS plus ATP induced inflammatory response in cardiac fibroblasts. Inflammation 2015, 38, 94-101. [CrossRef]

107. Harborne, J.B.; Williams, C.A. Advances in flavonoid research since 1992. Phytochemistry 2000, 55, 481-504. [CrossRef]

108. Batra, P.; Sharma, A.K. Anticancer potential of flavonoids: Recent trends and future perspectives. 3 Biotech $2013,3,439-459$. [CrossRef]

109. Knekt, P.; Jarvinen, R.; Seppanen, R.; Hellovaar, M.; Teppo, L.; Pukkala, E.; Aromaa, A. Dietary flavonoids and the risk of lung cancer and other malignant neoplasms. Am. J. Epidemiol. 1997, 146, 223-230. [CrossRef]

110. Birt, D.F.; Hendrich, S.; Wang, W. Dietary agents in cancer prevention: Flavonoids and isoflavonoids. Pharmacol. Ther. 2001, 90, 157-177. [CrossRef]

111. Neuhouser, M.L. Dietary flavonoids and cancer risk: Evidence from human population studies. Nutr. Cancer 2004, 50, 1-7. [CrossRef] [PubMed]

112. Yang, S.F.; Yang, W.E.; Chang, H.R.; Chu, S.C.; Hsieh, Y.S. Luteolin induces apoptosis in oral squamous cancer cells. J. Dent. Res. 2008, 87, 401-406. [CrossRef]

113. Ju, W.; Wang, X.; Shi, H.; Chen, W.; Belinsky, S.A.; Lin, Y. A critical role of luteolin induced reactive oxygen species in blockage of tumor necrosis factor activated nuclear factor kappa B pathway and sensitization of apoptosis in lung cancer cells. Mol. Pharmacol. 2007, 71, 1381-1388. [CrossRef] [PubMed]

114. Zhang, Q.; Zhao, X.H.; Wang, Z.J. Flavones and flavonols exert cytotoxic effects on a human oesophageal adenocarcinoma cell line (OE33) by causing G2/M arrest and inducing apoptosis. Food Chem. Toxicol. 2008, 46, 2042-2053. [CrossRef]

115. Chiu, F.L.; Lin, J.K. Down regulation of androgen receptor expression by luteolin causes inhibition of cell proliferation and induction of apoptosis in human prostate cancer cells and xenografts. Prostate 2008, 68, 61-71. [CrossRef]

116. Lin, Y.; Shi, R.; Wang, X.; Shen, H.M. Luteolin, a flavonoid with potentials for cancer prevention and therapy. Curr. Cancer Drug Targets 2008, 8, 634-646. [CrossRef]

117. Harborne, J.B.; Baxter, H. The Handbook of Natural Flavonoids; John Wiley and Sons: Chichester, UK, $1999 ;$ Volume 1, p. 12.

118. Hostetler, G.L.; Ralston, R.A.; Schwartz, S.J. Flavones: Food sources, bioavailability, metabolism, and bioactivity. Adv. Nutr. 2017, 8, 423-435. [CrossRef]

119. Falcone-Ferreyra, M.L.; Rius, S.P.; Casati, P. Flavonoids: Biosynthesis, biological functions, and biotechnological applications. Front. Plant. Sci. 2012, 3, 222. [CrossRef]

120. Kabera, J.N.; Semana, E.; Mussa, A.R.; He, X. Plant secondary metabolites: Biosynthesis, classification, function and pharmacological properties. J. Pharm. Pharmacol. 2014, 2, 377-392.

121. Seo, H.S.; Ku, J.M.; Choi, H.S.; Woo, J.K.; Jang, B.H.; Shin, Y.C.; Ko, S.G. Induction of caspase-dependent apoptosis by apigenin by inhibiting STAT3 signalling in HER2-overexpressing MDA-MB-453 breast cancer cells. Anticancer Res. 2014, 34, $2869-2882$.

122. Salehi, B.; Venditti, A.; Sharifi-Rad, M.; Kregiel, D.; Sharifi-Rad, J.; Durazzo, A.; Lucarini, M.; Santini, A.; Souto, E.B.; Novellino, E.; et al. The therapeutic potential of apigenin. Int. J. Mol. Sci. 2019, 20, 1305. [CrossRef] [PubMed]

123. Li, R.; Zhao, D.; Qu, R.; Fu, Q.; Ma, S. The effects of apigenin on lipopolysaccharide induced depressive like behavior in mice. Neurosci. Lett. 2015, 594, 17-22. [CrossRef] [PubMed]

124. Pamunuwa, G.; Karunaratne, D.N.; Waisundara, V.Y. Antidiabetic properties, bioactive constituents, and other therapeutic effects of Scoparia dulcis. Evid. Based Complement. Alternat. Med. 2016, 16, 824-830.

125. Tang, R.; Chen, K.; Cosentino, M.; Lee, K.H. Apigenin-7-O- $\beta$-D-glucopyranoside, an anti-HIV principle from Kummerowia Striata. Bioorg. Med. Chem. Lett. 1994, 4, 455-458. [CrossRef]

126. Ali, F.; Naz, F.; Jyoti, S.; Siddique, Y.H. Health functionality of apigenin: A review. Int. J. Food Prop. 2017, 20, 1197-1238. [CrossRef]

127. Kaur, R.; Sharma, P.; Gupta, G.K.; Ntie-Kang, F.; Kumar, D. Structure activity relationship and mechanistic insights for anti-HIV natural products. Molecules 2020, 25, 2070. [CrossRef] [PubMed]

128. Erlund, I. Review of the flavonoids quercetin, hesperetin, and naringenin: Dietary sources, bioactivities, bioavailability, and epidemiology. Nutr. Res. 2004, 24, 851-874. [CrossRef]

129. Rani, N.; Bharti, S.; Krishnamurthy, B.; Bhatia, J.; Sharma, C.; Kamal, M.A.; Ojha, S.; Arya, D.S. Pharmacological properties and therapeutic potential of naringenin: A citrus flavonoid of pharmaceutical promise. Curr. Pharm. Des. 2016, 22, 1-19. [CrossRef]

130. Jadeja, R.N.; Devkar, R.V. Polyphenols and flavonoids in controlling non-alcoholic steatohepatitis. In Polyphenols in Human Health and Disease; Academic Press: San Diego, CA, USA, 2014; Volume 1, pp. 615-623.

131. Mbaveng, A.T.; Zhao, Q.; Kuete, V. Harmful and protective effects of phenolic compounds from African medicinal plants. In Toxicological Survey of African Medicinal Plants, 1st ed.; Kuete, V., Ed.; Elsevier: New York, NY, USA, 2014; Volume 1, Chapter 20; pp. 577-609.

132. Pinho-Ribeiro, F.A.; Zarpelon, A.C.; Fattori, V.; Manchope, M.F.; Mizokami, S.S.; Casagrande, R.; Verri, W.A. Naringenin reduces inflammatory pain in mice. Neuropharmacology 2016, 105, 508-519. [CrossRef] [PubMed] 
133. Zobeiri, M.; Belwal, T.; Parvizi, F.; Naseri, R.; Farzaei, M.H.; Nabavi, S.F.; Sureda, A.; Nabavi, S.M. Naringenin and its nanoformulations for fatty liver: Cellular modes of action and clinical perspective. Curr. Pharm. Biotechnol. 2018, 19, $196-205$. [CrossRef] [PubMed]

134. Salehi, B.; Fokou, P.V.T.; Sharifi-Rad, M.; Zucca, P.; Pezzani, R.; Martins, N.; Sharifi-Rad, J. The therapeutic potential of naringenin: A review of clinical trials. Pharmaceuticals 2019, 12, 11. [CrossRef]

135. Wang, N.; Li, D.; Lu, N.H.; Yi, L.; Huang, X.W.; Gao, Z.H. Peroxynitrite and haemoglobin mediated nitrative/oxidative modification of human plasma protein: Effects of some flavonoids. J. Asian Nat. Prod. Res. 2010, 12, 257-264. [CrossRef]

136. Arul, D.; Subramanian, P. Naringenin (citrus flavanone) induces growth inhibition, cell cycle arrest and apoptosis in human hepatocellular carcinoma cells. Pathol. Oncol. Res. 2013, 19, 763-770. [CrossRef] [PubMed]

137. Chandrika, B.B.; Steephan, M.; Kumar, T.R.S.; Sabu, A.; Haridas, M. Hesperetin and naringenin sensitize HER2 positive cancer cells to death by serving as HER2 tyrosine kinase inhibitors. Life Sci. 2016, 160, 47-56. [CrossRef]

138. Lim, W.; Park, S.; Bazer, F.W.; Song, G. Naringenin induced apoptotic cell death in prostate cancer cells is mediated via the PI3K/AKT and MAPK signalling pathways. J. Cell. Biochem. 2017, 118, 1118-1131. [CrossRef]

139. Hernandez-Aquino, E.; Muriel, P. Beneficial effects of naringenin in liver diseases: Molecular mechanisms. World J. Gastroenterol. 2018, 24, 1679-1707. [CrossRef]

140. Kapoor, R.; Rizvi, F.; Kakkar, P. Naringenin prevents high glucose induced mitochondria mediated apoptosis involving AIF, Endo-G and caspases. Apoptosis 2013, 18, 9-27. [CrossRef] [PubMed]

141. Kapoor, R.; Kakkar, P. Naringenin accords hepato protection from streptozotocin induced diabetes in vivo by modulating mitochondrial dysfunction and apoptotic signalling cascade. Toxicol. Rep. 2014, 1, 569-581. [CrossRef]

142. Kreft, S.; Knapp, M.; Kreft, I. Extraction of rutin from buckwheat (Fagopyrum esculentum Moench) seeds and determination by capillary electrophoresis. J. Agric. Food Chem. 1999, 47, 4649-4652. [CrossRef] [PubMed]

143. Javed, H.; Khan, M.M.; Ahmad, A.; Vaibhav, K.; Ahmad, M.E.; Khan, A.; Ashafaq, M.; Islam, F.; Siddiqui, M.S.; Safhi, M.M.; et al. Rutin prevents cognitive impairments by ameliorating oxidative stress and neuro inflammation in rat model of sporadic dementia of Alzheimer type. Neuroscience 2012, 17, 340-352. [CrossRef] [PubMed]

144. Trumbeckaite, S.; Bernatoniene, J.; Majiene, D.; Jakstas, V.; Savickas, A.; Toleikis, A. The effect of flavonoids on rat heart mitochondrial function. Biomed. Pharmacother. 2006, 60, 245-248. [CrossRef] [PubMed]

145. Al-Dhabi, N.A.; Arasu, M.V.; Park, C.H.; Park, S.U. An up-to-date review of rutin and its biological and pharmacological activities. EXCLI J. 2015, 14, 59-63. [PubMed]

146. Enogieru, A.B.; Haylett, W.; Hiss, D.C.; Bardien, S.; Ekpo, O. Rutin as potent antioxidants: Implications for neurodegenerative disorders. Oxid. Med. Cell. Longev. 2018, 4, 1-17. [CrossRef] [PubMed]

147. La Casa, C.; Villegas, I.; De La Lastra, C.A.; Motilva, V.; Martin, C.M.J. Evidence for protective and antioxidant properties of rutin, a natural flavone, against ethanol induced gastric lesions. J. Ethnopharmacol. 2000, 71, 45-53. [CrossRef]

148. Perk, A.A.; Mytsyk, I.S.; Gerçek, Y.C.; Boztas, K.; Yazgan, M.; Fayyaz, S.; Farooq, A.A. Rutin mediated targeting of signalling machinery in cancer cells. Cancer Cell Int. 2014, 14, 124-130. [CrossRef] [PubMed]

149. Mellou, F.; Loutrari, H.; Stamatis, H.; Roussos, C.; Kolisis, F.N. Enzymatic esterification of flavonoids with unsaturated fatty acids: Effect of the novel esters on vascular endothelial growth factor release from K562 cells. Process. Biochem. 2006, 41, $2029-3204$. [CrossRef]

150. Schwedhelm, E.; Maas, R.; Troost, R.; Boger, R.H. Clinical pharmacokinetics of antioxidants and their impact on systemic oxidative stress. Clin. Pharmacokinet. 2003, 42, 437-459. [CrossRef]

151. Ganeshpurkar, A.; Saluja, A.K. The pharmacological potential of Rutin. Saudi Pharm. J. 2017, 25, 149-164. [CrossRef]

152. Kerry, N.L.; Abbey, M. Red wine and fractionated phenolic compounds prepared from red wine inhibit low density lipoprotein oxidation in vitro. Atherosclerosis 1997, 135, 93-102. [CrossRef]

153. Erlejman, A.G.; Verstraeten, S.V.; Fraga, C.G.; Oteiza, P.I. The interaction of flavonoids with membranes: Potential determinant of flavonoid antioxidant effects. Free Radic. Res. 2014, 38, 1311-1320. [CrossRef] [PubMed]

154. Tapas, A.R.; Sakarkar, D.M.; Kakde, R.B. Flavonoids as nutraceuticals: A review. Trop. J. Pharm. Res. 2008, 7, 1089-1099. [CrossRef]

155. Middleton, E.; Kandaswami, C.; Theoharides, T.C. The effects of plant flavonoids on mammalian cells: Implications for inflammation, heart disease and cancer. Pharmacol. Rev. 2000, 52, 673-751. [PubMed]

156. Rocha, L.D.; Monterio, M.C.; Teodoro, A.J. Anticancer properties of hydroxycinnamic acids: A review. J. Cancer Res. Clin. Oncol. 2012, 1, 109-121. [CrossRef]

157. Badhani, B.; Sharma, N.; Kakkar, R. Gallic acid: A versatile antioxidant with promising therapeutic and industrial applications. RSC Adv. 2015, 5, 27540-27557. [CrossRef]

158. Heleno, S.A.; Martins, A.; Queiroz, M.J.; Ferreira, I.C. Bioactivity of phenolic acids: Metabolites versus parent compounds: A review. Food Chem. 2015, 173, 501-513. [CrossRef]

159. Yokozawa, T.; Chen, C.P.; Dong, E.; Tanaka, T.; Nonaka, G.I.; Nishioka, I. Study on the inhibitory effect of tannins and flavonoids against DPPH radical. J. Agric. Food Chem. 1998, 56, 213-222.

160. Akinmoladun, A.C.; Ibukun, E.O.; Afor, E.; Obuotor, E.M.; Farombi, E.O. Phytochemical constituent and antioxidant activity of extract from the leaves of Ocimum gratissimum. Sci. Res. Ess. 2007, 2, 163-166.

161. Kumar, N.; Goel, N. Phenolic acids: Natural versatile molecules with promising therapeutic applications. Appl. Biotechnol. Rep. 2019, 24, e00370. [CrossRef] 
162. Del-Rio, D.; Costa, L.G.; Lean, M.E.J.; Crozier, A. Polyphenols and health. Nutr. Metab. Cardiovasc. Dis. 2010, 20, 1-6. [CrossRef] [PubMed]

163. Anand, K.K.; Singh, B.; Saxena, A.K.; Chandan, B.K.; Gupta, V.N.; Bhardwaj, V. 3,4,5-Trihydroxy benzoic acid (Gallic Acid) the hepatoprotective principle in the fruits of Terminalia belerica bioassay guided activity. Pharmacol. Res. 1997, 36, 315-321. [CrossRef] [PubMed]

164. Da Silva, S.; Chaar, J.; Yano, T. Chemotherapeutic potential of two gallic acid derivative compounds from leaves of Casearia sylvestris (Flacourtiaceae). Eur. J. Pharmacol. 2009, 608, 76-83. [CrossRef] [PubMed]

165. Chanwitheesuk, A.; Teerawutgulrag, A.; Kilburn, J.D.; Rakariyatham, N. Antimicrobial gallic acid from Caesalpinia mimosoides Lamk. Food Chem. 2007, 100, 1044-1048. [CrossRef]

166. Kahkeshani, N.; Farzaei, F.; Fotouhi, M.; Alavi, S.S.H.; Bahramsoltani, R.; Naseri, R.; Momtaz, S.; Abbasabadi, Z.; Rahimi, R.; Farzaei, M.H.; et al. Pharmacological effects of gallic acid in health and diseases: A mechanistic review. Iran. J. Basic Med. Sci. 2019, 22, 225-237.

167. Park, J.; Han, W.; Park, J.; Choi, S.; Choi, J. Changes in hepatic drug metabolizing enzymes and lipid peroxidation by methanol extract and major compound of Orostachys japonicus. J. Ethnopharmacol. 2005, 102, 313-318. [CrossRef]

168. Choubey, S.; Goyal, S.; Varughese, L.R.; Kumar, V.; Sharma, A.K.; Beniwal, V. Probing Gallic Acid for Its Broad-Spectrum Applications. Mini Rev. Med. Chem. 2018, 18, 1283-1293. [CrossRef]

169. Chung, K.T.; Wong, T.Y.; Wei, C.; Huang, Y.W.; Lin, Y. Tannins and human health: A review. Crit. Rev. Food Sci. Nutr. 1998, 38, 421-464. [CrossRef]

170. Hussein, I.A.S.; Mona-Mansour, M.S.M. Polyphenols: Properties, occurrence, content in food and potential effects. J. Environ. Sci. Eng. 2017, 6, 232-261.

171. Tillman, P.B. Determination of nutrient values for commercial amino acids. J. Appl. Poult. Res. 2019, 28, 526-530. [CrossRef]

172. WHO; FAO; UNO. Protein and amino acid requirements in human nutrition, report of a joint WHO/FAO/UNU expert consultation. In WHO Technical Report Series No; WHO: Geneva, Switzerland, 2007; p. 935. Available online: https://apps.who. int/iris/handle/10665/43411 (accessed on 1 May 2021).

173. Arunachalam, K.; Parimelazhagan, T. Evaluation of nutritional composition and antioxidant properties of underutilized Ficus talboti King fruit for nutraceuticals and food supplements. J. Food Sci. Technol. 2014, 51, 1260-1268. [CrossRef]

174. Block, R.J.; Drrum, E.L.; Zweig, G. A Manual of Paper Chromatography and Electrophoresis, 2nd ed.; Academic Press: New York, NY, USA, 1958; p. 494.

175. Patridge, S.M. Aniline hydrogen phthalate as a spraying reagent for chromatography of sugars. Nature 1949, 164, 443. [CrossRef]

176. The Indian Pharmacopoeia; Government of India, Ministry of Health and Family Welfare, Addendum 2000; The Controller of Publications: Delhi, India, 1996; Volume 4, pp. 495-499.

177. United States Pharmacopoeia. The National Formulary; The United States Pharmacopoeial Convention, Inc.: Rockville, MD, USA, 2000; p. 20852.

178. Yen, G.C.; Chen, H.Y. Relationship between antimutagenic activity and major components of various teas. Mutagenesis 1996, 11, 37-41. [CrossRef]

179. Carr, A.C.; Frei, B. Toward a new recommended dietary allowance for vitamin $\mathrm{C}$ based on antioxidant and health effects in humans. Am. J. Clin. Nutr. 1999, 69, 1086-1107. [CrossRef] [PubMed]

180. Padyatty, S.J.; Katz, A.; Wang, Y.; Eck, P.; Kwon, O.; Lee, J.H.; Chen, S.; Corpe, C.; Dutta, A.; Dutta, S.K.; et al. Vitamin C as an antioxidant: Evaluation of its role in disease prevention. J. Am. Coll. Nutr. 2003, 22, 18-35. [CrossRef] [PubMed]

181. Tada, A.; Miura, H. The relationship between vitamin $C$ and periodontal disease: A systematic review. Int. J. Environ. Res. 2019, 16, 2472. [CrossRef] [PubMed]

182. FAO. Food and Agriculture; Statistic Series no. 94; Food and Agriculture Organisation: Rome, Italy, 1990.

183. Malik, A.H.; Khuroo, A.A.; Dar, G.H.; Khan, Z.S. The woody flora of Jammu and Kashmir State, India, An updated checklist. J. Econ. Taxon. Bot. 2010, 32, 274-292.

184. Mukherjee, P.K. Quality Control and Evaluation of Herbal Drug, 1st ed.; Business Horizon Publication: New Delhi, India, 2002; pp. 186-193.

185. Al-Owaisi, M.; Al-Hadiwi, N.; Khan, S.A. GC-MS analysis, determination of total phenolics, flavonoid content and free radical scavenging activities of various crude extracts of Moringa peregrina (Forssk.) Fiori leaves. Asian Pac. J. Trop. Biomed. 2014, 4, 964-970. [CrossRef]

186. Abdel-Aal, E.I.; Haroon, A.M.; Mofeed, J. Successive solvent extraction and GC-MS analysis for the evaluation of the phytochemical constituents of the filamentous green alga Spirogyra longata. Egypt. J. Aquat. Res. 2015, 41, 233-246. [CrossRef]

187. Gupta, K.K.; Kumar, A. Leaf chemistry and food selection by common Langurs (Presbytis entellus) in Rajaji National Park, Uttar Pradesh, India. Int. J. Primatol. 1994, 15, 75-93. [CrossRef]

188. Reddy, K.N.; Pattanaik, C.; Reddy, C.S.; Raju, V.S. Traditional knowledge of wild food plants in Andhra Pradesh. Indian J. Tradit. Knowl. 2007, 6, 223-229.

189. Yadav, R.K.; Mishra, A. Aromatic wild-type plants at terai region of Uttar Pradesh with traditional knowledge. Ann. Phytomed. 2015, 4, 106-111.

190. Dutta, B.K.; Dutta, P.K. Potential of ethnobotanical studies in North East India: An overview. Indian J. Tradit. Knowl. 2005, 4, 7-14. 
191. Abad, M.J.; Bermejo, P.; Carretero, E.; Martinez-Acitores, C.; Noguera, B.; Villar, A. Antiinflammatory activity of some medicinal plant extracts from Venezuela. J. Ethnopharmacol. 1996, 55, 63-68. [CrossRef]

192. Szeto, Y.T.; Tomlinson, B.; Benzie, I.F. Total antioxidant and ascorbic acid content of fresh fruits and vegetables: Implications for dietary planning and food preservation. Br. J. Nutr. 2002, 87, 55-59. [CrossRef] [PubMed]

193. Tsai, C.C.; Lin, C.C. Anti-inflammatory effects of Taiwan folk medicine "Teng-Khaia-U" on carrageenan and adjuvant induced paw edema in rats. J. Ethnopharmacol. 1999, 64, 85-89. [CrossRef]

194. Nielen, M.M.; Schaardenburg, D.V.; Reesink, H.W.; Twisk, J.W.R.; Van De Stadt, R.J.; Vander Horst, B.I.E.; De Koning, M.H.; Habibuw, M.R.; Dijkman, B.A. Simultaneous development of acute phase response and auto-antibodies in preclinical rheumatoid arthritis. Ann. Rheum. Dis. 2006, 65, 535-537. [CrossRef] [PubMed]

195. Kamalutheen, M.; Gopalakrishnan, S.; Ismail, T.S. Anti-inflammatory and antiarthritic activities of Merremia tridentate (L.). J. Chem. 2009, 6, 943-948.

196. Patil, K.S.; Suryavanshi, J. Effect of Celastrus paniculatus wild seed on adjuvant induced arthritis in rats. Pharmacogn. Mag. 2007, 3, 177-181.

197. Hu, F.; Hepburn, H.R.; Li, Y.; Chen, M.; Radloff, S.E.; Daya, S. Effect of ethanol and water extracts of Propolis (bee glue) on acute inflammatory animal models. J. Ethnopharmacol. 2005, 10, 276-283. [CrossRef]

198. Srinivasan, R.; Chandrasekar, M.J.N.; Nanjan, M.J.; Suresh, B. Antioxidant activity of Caesalpinia digyna root. J. Ethnopharmacol. 2007, 113, 284-291. [CrossRef] [PubMed]

199. Kumaraswamy, M.V.; Satish, S. Antioxidant and anti-lipoxygenase activity of Thespesia lampas Dalz and Gibs. Adv. Biol. Res. 2008, 2, 56-59.

200. Badami, S.; Gupta, M.K.; Suresh, B. Antioxidant activity of ethanolic extract of Striga orobanchioides. J. Ethnopharmacol. 2003, 85, 227-230. [CrossRef]

201. Pisoschi, A.M.; Negulescu, G.P. Methods for total antioxidant activity determination: A review. Anal. Biochem. 2011, 4, 1-10. [CrossRef]

202. Sultana, B.; Anwar, F.; Ashraf, M. Effect of extraction solvent/technique on the antioxidant activity of selected medicinal plant extracts. Molecules 2009, 14, 2167-2180. [CrossRef]

203. Saad, R.; Asmani, F.; Saad, M.; Hussain, M.; Khan, J.; Kaleemullah, M.; Othman, N.B.; Tofigh, A.; Yusuf, E. A new approach for predicting antioxidant property of herbal extracts. Int. J. Pharmacogn. Phytochem. Res. 2015, 7, 166-174.

204. Torane, R.C.; Kamble, G.S.; Khatiwor, E.; Ghayal, N.A.; Deshpande, N.R. Antioxidant capacity of leaves and stem of Ehretia laevis. Int. J. Pharm. Pharm. Sci. 2011, 3, 149-151.

205. Florence, T.M. The role of free radicals in disease. Aust. N. Z. J. Ophthalmol. 1995, 23, 3-7. [CrossRef]

206. Cook, N.C.; Samman, S. Flavonoid chemistry, metabolism, cardio protective effects and dietary sources. J. Nutr. Biochem. 1996, 7, 66-76. [CrossRef]

207. Kumpulainen, J.T.; Salonen, J.T. Natural Antioxidants and Anticarcinogens in Nutrition, Health and Disease. R. Soc. Chem. 1999, 5, 178-187.

208. Adibhatla, R.M.; Hatcher, J.F. Altered lipid metabolism in brain injury and disorders. Subcell. Biochem. 2008, 49, $241-268$.

209. Valsaraj, R.; Pushpangadan, P.; Smitt, U.W.; Adsersen, A.; Nyman, U. Antimicrobial screening of selected medicinal plants from India. J. Ethnopharmacol. 1997, 58, 75-83. [CrossRef]

210. Aqil, F.; Ahmad, I. Broad-spectrum antibacterial and antifungal properties of certain traditionally used Indian medicinal plants. World J. Microbiol. Biotechnol. 2003, 19, 653-657. [CrossRef]

211. Jan, S.; Hamayun, M.; Ahmad, N.; Khan, A.L.; Iqbal, A.; Rehman, K.U.; Nawaz, Y.; Lee, I. Antibacterial potential of plants traditionally used for curing diarrhea in Khyber Pakhtunkhwa, Pakistan. J. Med. Plant. Res. 2012, 6, 4039-4047.

212. Mutha, M.; Deshpande, R.R.; Patil, V.; Shep, S.; Deshpande, N.R.; Torne, R. Comparative evaluation of antibacterial properties of different extracts of Mimusops Elengi (Bakul) and Ehretia laevis (Ajaan) against salivary microflora. Asian J. Pharm. Clin. Res. 2015, 8, 217-219.

213. Jadhav, M.V.; Deshpande, R.R.; Dadpe, M.; Mahajan, P.; Kakade, P.; Kamble, G.; Deshpande, N.R. Screening of antimicrobial activity of active compounds of Embelia basal, chlorhexidine and amoxicillin against salivary microflora of mixed dentition age group. Res. J. Pharm. Biol. Chem. 2012, 3, 1334-1339.

214. Murarkar, K.; Bande, D.; Chandak, A. Antimicrobial activity and minimum inhibitory concentration of Ehretia laevis leaves extracts against different microorganisms. World J. Pharm. Res. 2018, 7, 691-697.

215. Bibi, Y.; Naeem, J.; Zahara, K.; Arshad, M.; Qayyum, A. In vitro antimicrobial assessment of selected plant extracts from Pakistan. Iran. J. Sci. Technol. 2018, 42, 267-272. [CrossRef]

216. Gupta, N.; Gupta, S.K.; Shukla, V.K.; Singh, S.P.J. An Indian community based epidemiological study of wounds. Wound Care 2004, 13, 323-325. [CrossRef]

217. Thakre, R.; Bhutada, S.; Chouragade, B.; Khobragade, P.; Ketaki, H. Unexpected wound healing property of Ehretia laevis Roxb. (Khandu Chakka) plant. Int. J. Res. Ayurveda Pharm. 2016, 7, 54-57. [CrossRef]

218. Rao, M.; Kumar, P.; Das, B. Comparative study of efficacy of Jatyadi Ghrita Pichu and Yasthimadhu Ghrita Pichu in the management of parikartika (fissure-in-ano). Int. J. Ayurveda Pharma Res. 2016, 4, 1-9.

219. Samantaray, S.; Bishwal, R.; Singhai, S. Clinical efficacy of jatyadi taila in parikartika (fissure-in-ano). World J. Pharm. Med. Res. 2017, 3, 250-254. 
220. Tichkule, S.V.; Khandare, K.B.; Shrivastav, P.P. Proficiency of Khanduchakka Ghrit in the management of Parikartika: A case report. Indian J. Med. Res. 2019, 7, 47-50. [CrossRef]

221. Tefere, Y.; Chanie, S.; Dessie, T.; Gedamu, H. Assessment of prevalence of dental caries and the associated factors among patients attending dental clinics in Debre Tabor general hospital: A hospital based cross sectional study. BMC Oral Health 2018, 18, 119-125. [CrossRef]

222. Deshpande, R.; Walimbe, H.; Jadhav, M.; Deshpande, N.; Devare, S. Comparative evaluation of antimicrobial activity of various extracts of 'Morinda pubescens' in different concentration on human salivary microflora. Int. J. Pharm. Pharm. Sci. 2013, 5, 910-912.

223. Hiremath, A.; Murugaboopathy, V.; Ankola, A.V.; Hebbal, M.; Mohandoss, S.; Pastay, P. Prevalence of dental caries among primary school children of India: A cross-sectional study. J. Clin. Diagn. Res. 2016, 10, 47-50. [CrossRef] [PubMed]

224. Deshpande, R.; Khare, A.; Shah, A.; Mutha, M.; Deshpande, N. Going back to where it all started: An overview of five medicinal plants. Int. J. Contemp. Med. Res. 2015, 2, 1392-1396.

225. Shah, A.; Marwat, S.K.; Gohar, F.; Khan, A.; Bhatti, K.H.; Amin, M.; Din, N.U.; Ahmad, M.; Zafar, M. Ethnobotanical study of medicinal plants of semi-tribal area of Makerwal \& Gulla Khel (lying between Khyber Pakhtunkhwa and Punjab Provinces), Pakistan. Am. J. Plant. Sci. 2013, 4, 98-116.

226. Kumar, P.R. Ethno medicinal plants used for oral health care in India. Int. J. Herb. Med. 2014, 2, 81-87.

227. Deshpande, R.; Patil, V.; Shah, H.; Ruikar, A.; Gaikwad, S.; Kamble, G.; Mundhe, K.; Adsul, V. Back to mother nature: Novel herbal medicines in preventing dental caries. J. Dent. 2018, 113, 295-311.

228. Bande, D.; Murarkar, K. Blood coagulation properties of Khandu Chakka (Ehretia laevis) plant leaves. Int. J. Curr. Res. Life Sci. 2018, 7, 2220-2222.

229. Tichkule, S.V.; Khandare, K.B.; Shrivastav, P.P. Role of Khanduchakka (Ehretia laevis) Lepan (local application) in the management of delayed union of metatarsal fracture: A case report. J. Indian Sys. Med. 2019, 7, 127-130. [CrossRef]

230. Shisha, T. Parameters for defining efficacy in fracture healing. Clin. Cases Miner. Bone Metab. 2010, 7, 15-16.

231. Mohiuddin, M.; Arbain, D.; Islam, A.K.; Rahman, M.; Ahmad, M.S.; Ahmad, M.N. Electrochemical measurement of the antidiabetic potential of medicinal plants using multi-walled carbon nanotubes paste electrodes. Russ. J. Electrochem. 2015, 51, 368-375. [CrossRef]

232. Ecobichon, D.J. The Basis of Toxicology Testing; CRC Press: New York, NY, USA, 1997; pp. $43-86$.

233. Goel, R.K.; Singh, D.; Lagunin, A.; Poroikov, V. PASS-assisted exploration of new therapeutic potential of natural products. Med. Chem. Res. 2011, 20, 1509-1514. [CrossRef]

234. Gaikwad, K.N.; Mali, M.V. Tree flora of Nashik city, Maharashtra. Int. J. Life Sci. Pharm. Res. 2012, 2, 94-101.

235. Rohini, I.; Jirouthu, B.; Kumar, N.S.; Bhavya, C.; Kumar, K.S. An ethno-medicinal survey of medicinal plants used by traditional healers of Araku valley, Andhra Pradesh, India. Int. J. Curr. Res. 2017, 9, 48633-48645. 